\title{
Virtually No Effect? Different Uses of Classroom Computers and their Effect on Student Achievement"
}

\author{
Oliver Falck, Constantin Mang, and Ludger Woessmann ${ }^{\dagger}$
}

\begin{abstract}
Most studies find little to no effect of classroom computers on student achievement. We suggest that this null effect may combine positive effects of computer uses without equivalently effective alternative traditional teaching practices and negative effects of uses that substitute more effective teaching practices. Our correlated random effects models exploit within-student between-subject variation in different computer uses in the international TIMSS test. We find positive effects of using computers to look up information and negative effects of using computers to practice skills, resulting in overall null effects. Effects are smaller for low-SES students and mostly confined to developed countries.
\end{abstract}

Keywords: Computers, teaching methods, student achievement, TIMSS

JEL classification: I21, I28

February 9, 2015

Preliminary. Please do not cite or circulate. Comments welcome.

\footnotetext{
* For helpful comments, we would like to thank Eric Bettinger, Mat Chingos, Tom Dee, Rob Fairlie, David Figlio, and seminar participants at Stanford University, IZA Bonn, the Ifo Institute, and the III Id ICT Conference Munich. Woessmann is grateful to the Hoover Institution at Stanford University for its hospitality during work on this paper.

† Ifo Institute at the University of Munich. Emails: falck@ifo.de, constantin@mangmail.de, and woessmann@ifo.de.
} 


\section{Introduction}

The use of computer-based teaching methods and virtual learning technologies in the classroom has raised high expectations to improve educational achievement (e.g., Peterson, 2010; Economist, 2013). These methods are often seen as the biggest technology shift in decades, if not in centuries, set to revolutionize the traditional teacher-centric lecturing style and to unleash the potential for improvements in teaching quality and efficiency. However, the empirical evidence on the effects of computers on student achievement has been disappointing, mostly finding no effects (Bulman and Fairlie, 2014). This paper suggests that such null effects may be the result of a combination of using computers for activities that are more productive than traditional teaching methods, thus improving student outcomes, and using computers in ways that substitute more effective traditional practices, thus lowering student outcomes. Our evidence shows that using computers to look up ideas and information indeed improves student achievement, but using computers to practice skills reduces student achievement.

The central point in our reasoning is that there are opportunity costs of time. Every classroom minute can be used for one activity or another. Thus, if the time spent on computers is increased, it substitutes different alternative time uses. On the one hand, computers can be used for specific applications, such as exploring new ideas and information on the Internet, that do not have comparably effective alternatives in the traditional world. If these computer uses substitute less effective uses of classroom time, student learning will increase. On the other hand, computers can be used for more traditional applications, such as practicing skills, that have potentially more effective conventional teaching alternatives. If these are crowded out, student learning will decrease. Thus, the net effect of computer use depends on the specific activities that they are used for and the relative effectiveness of the activities that they crowd out. An overall null effect of computer use may be the sum of positive and negative effects.

We test this hypothesis using information on the specific uses of computers in the classroom in the Trends in International Mathematics and Science Study (TIMSS). The 2011 TIMSS test covers the math and science achievement of over 150,000 students in 30 countries in $8^{\text {th }}$ grade and nearly 250,000 students in 53 countries in $4^{\text {th }}$ grade. In detailed background questionnaires, TIMSS surveys how often teachers in each subject have their students use computers in three distinct activities: look up ideas and information; practice skills and procedures; and (only in $8^{\text {th }}$ grade) process and analyze data. Apart from enabling an analysis of different types of computer uses, the international character of the TIMSS data allows us to test whether any effect is context-specific or generalizes to other settings. 
Our identification strategy exploits the two-subject structure of the TIMSS data. It is hard to imagine a field experiment that would assign different types of computer uses randomly across classrooms, not least because of teacher resistance. But in observational data, it is not random which students and classrooms use computers. For example, the availability of computers in a school is likely related to the socioeconomic status of the neighborhood, and teachers may choose to use computers based on students' achievement levels. To avoid bias from nonrandom selection of students into specific schools or classrooms, our empirical model identifies from variation in computer use across subjects within individual students. This between-subject variation allows us to estimate within-student effects, holding subject-invariant unobserved school and student characteristics constant. We generalize between-subject models with student fixed effects that assume the same effect of computer use on student achievement in both subjects (e.g., Dee, 2005, 2007; Lavy, 2014) to correlated random effects models with subject-specific effects (Metzler and Woessmann, 2013), which prove empirically relevant in our setting. To address nonrandom computer choices by different teachers, we draw on the rich TIMSS background information on teachers and their teaching methods. To further rule out bias from unobserved teacher characteristics or nonrandom selection of teachers into computer use, we also identify from between-subject variation within the same teacher when restricting our $4^{\text {th }}$-grade analysis to a sample of students taught by the same teacher in both subjects.

In line with most of the literature, on average we do not find a significant effect of computer use on student achievement. But this null effect is the combination of positive and negative effects of specific computer uses: Using computers to look up ideas and information has a positive effect, whereas using computers to practice skills and procedures has a negative effect (and using computers to process and analyze data has no effect). In $8^{\text {th }}$ grade - which is the main focus of our analysis as computer use should be mature by this stage - this pattern is evident in science but not in math. Interestingly, while finding the same pattern of opposing use-specific effects in $4^{\text {th }}$ grade, there it is strongest in math. This might indicate that the positive effect of using computers to look up ideas and information is particularly pertinent in the explorative stages of a subject matter. In terms of effect sizes, going from no to daily computer use for looking up ideas and information increases $8^{\text {th }}$-grade science achievement by $10-13$ percent of a standard deviation (depending on the included controls), but it reduces achievement by 7-11 percent of a standard deviation when used to practice skills and procedures.

Looking across countries, results are strongest among OECD countries and mostly insignificant in less developed countries. There are no systematic differences along other country dimensions such as broadband access or the size of the country, indicating that general 
Internet familiarity and the size of the software market do not seem to be crucial. Results also do not differ systematically by gender or by individual levels of achievement or computer acquaintance, indicating that effects do not depend on individual competencies. However, effects are less pronounced for students from low socioeconomic background. The patterns suggest that results are mostly a general feature of specific computer uses. Results are also robust in the within-teacher specification that exploits that many $4^{\text {th }}$-grade students are taught by the same teacher in math and science.

Our results can reconcile some of the diverging findings in the literature. Most studies of computer use in school find little to no effect of classroom computers on student achievement, in particular when looking at investment in computer technologies in general. ${ }^{1}$ But there are exceptions of studies finding significant positive effects of specific computer-assisted instruction programs, ${ }^{2}$ and in all these cases, there are indications that computers are being put to more effective uses in the sense of our framework (see Section 2.2 for details). Our result that effects of classroom computers differ by their specific uses also relate to the recent literature on computers at home which emphasizes that home computers can be put to conducive uses such as schoolwork as well as detrimental uses such as gaming or entertainment (Fairlie and London, 2012; Fairlie and Robinson, 2013). The differential effects of computer use in school also mirror differential effects of ICT more generally, which has been found, for example, to have positive effects of increased economic growth (Czernich et al., 2011) and social interaction (Bauernschuster, Falck, and Woessmann, 2014), but also negative effects of reduced voter turnout (Falck, Gold, and Heblich, 2014) and increased sex crime (Bhuller et al., 2013).

Our results also have implications for policy. Recently, there has been a big push in many countries to bring computers into classrooms. Some U.S. school districts invest more than $\$ 1$ billion in classroom computers and corresponding infrastructure. ${ }^{3}$ Indeed, President Obama made technology in schools a priority of his education policy in the State of the Union Address 2014 and announced a multi-billion-dollar program to support the roll-out of technology in classrooms. ${ }^{4}$ A similar initiative in the European Union aims to equip every school with ICT

\footnotetext{
${ }^{1}$ E.g., Angrist and Lavy (2002), Rouse and Krueger (2004), Goolsbee and Guryan (2006), and Leuven et al. (2007); see Bulman and Fairlie (2014) for a review.

2 See Machin, McNally and Silva (2007), Banerjee et al. (2007), and Barrow, Markman, and Rouse (2009).

3 The Los Angeles Unified School District plans to spend \$1.3 billion on iPads and Wi-Fi infrastructure (http://www.scpr.org/blogs/education/2014/02/11/15811/la-schools-wifi-networks-to-cost-about-800-million).

${ }^{4}$ Within the scope of the ConnectEd initiative, the Federal Communications Commission (FCC) will spend $\$ 2$ billion over the next two years to connect classrooms. Additionally, private companies, such as Microsoft and Apple, have committed more than $\$ 1$ billion to support the roll-out of new technologies into classrooms (http://www.whitehouse.gov/issues/education/k-12/connected).
} 
equipment by $2020 .^{5}$ Our results imply that the success of any such initiative will depend on the specific uses that the extended computer exposure in the classroom will be brought to.

In what follows, Section 2 provides a conceptual framework for our analysis that also helps to conceptualize the existing literature. Section 3 introduces the TIMSS data and Section 4 our identification strategy. Sections 5 and 6 present our results in $8^{\text {th }}$ and $4^{\text {th }}$ grade, respectively. Section 7 analyzes heterogeneity by students and countries. Section 8 concludes.

\section{Conceptual Framework and Related Literature}

\subsection{Conceptual Framework: Opportunity Costs of Computer-Assisted Instruction Time}

Computer-assisted instruction in the classroom has been argued to further student learning in many ways, including more effective use of time, individualized instruction, better monitoring of student progress, and improved access to world-wide information (e.g., Bulman and Fairlie, 2014). However, the net effect of any use of instruction time in school will depend on the opportunity cost of time. The marginal effect of using additional instruction time for any specific activity ultimately depends on the marginal productivity of time use in this activity relative to the marginal productivity of time use in the activity that it replaces. Consequently, there is a tradeoff between computer-assisted instruction and any traditional mode of instruction, such as teacher-centered group instruction or individual learning, that it offsets.

To fix ideas and frame the subsequent discussion, let us consider the learning process as a simple education production function (e.g., Hanushek, 2002) that places particular emphasis on different uses of classroom time (similar in spirit to Bulman and Fairlie, 2014). ${ }^{6}$ Educational achievement $A$ of a student (student and subject subscripts omitted for expositional simplicity) is a function $f$ of different inputs:

$$
A=f\left(X, S, \bigcup_{o, u} T_{u}^{o}\right) \quad \text { s.t. } \quad \sum_{o, u} T_{u}^{o} \leq \bar{T} \quad \text { with } o \in(t, c) \text { and } u \in(l, p, d, r)
$$

where $X$ refers to all out-of-school input factors (including individual ability, family background, and peers), $S$ refers to the quantity and quality of material and teacher inputs in school, and $T$ refers to different uses of classroom time. In particular, classroom time can be used in two specific modes $o$, and each can be put to a number of specific uses $u$. The two

\footnotetext{
${ }^{5}$ http://europa.eu/rapid/press-release_MEMO-13-813_en.htm.

${ }^{6}$ We limit our analysis to different intensities of computer-assisted instruction in the classroom and abstain from analysis of fully online courses or schools; see Chingos and Schwerdt (2014) for virtual schools and Figlio, Rush, and Yin (2013) and Bowen et al. (2014) for online courses in higher education.
} 
modes $o$ of time use are computer-assisted instruction $c$ and traditional instruction $t$. To emphasize typical computer-based classroom uses in our model framework, the four specific uses $u$ to which either of the modes can be put are looking up ideas and information $l$; practicing skills and procedures $p$; processing and analyzing data $d$; and any other use of time $r$.

The key feature is that classroom instruction is subject to a time budget constraint in that the sum of the different uses of classroom time cannot exceed total classroom time $\bar{T}$. This means that any use of classroom time in one activity is subject to an opportunity cost of time, since the same unit of time cannot be used for any other classroom activity. This simple framework helps us clarify a number of stereotypical assumptions about computer use in school.

First, there may be some activities in which, starting from low use intensities, the marginal productivity of computer-assisted instruction is superior to traditional instruction. For example, the World Wide Web provides access to a wealth of information in an easily accessible way that is simply not feasible in an offline mode. Therefore, we might expect $\partial A / \partial T_{l}^{c}>\partial A / \partial T_{l}^{t}$, i.e., the marginal product of using computers to look up ideas and information $l$ is larger than the marginal product of traditional modes, for example going to libraries to look up ideas and information. If computer-based instruction substitutes traditional instruction in the same use, using classroom computers to look up ideas and information will improve student learning.

Second, in other activities, traditional teaching methods may be more effective than computer-based alternatives. For example, some argue that when it comes to practicing skills and procedures $p$, traditional teaching methods may have reached a high level of perfection, whereas computer-based modes may distract from the main task. Moreover, for practicing your skills, it may often be important not to use the help of other devices. Thus, if $\partial A / \partial T_{p}^{c}<\partial A / \partial T_{p}^{t}$ using computers for practicing will reduce student achievement. Overall, the complementarity of computers to non-routine tasks like looking up ideas and information in the production of education by teachers and students, as well as their substitutability to routine tasks like practicing, may mirror more general ways in which computers affect the labor market (Autor, Levy, and Murnane, 2003).

Third, there may also be activities without strong priors about the relative productivity of computer-based and traditional teaching modes. If we call these uses $d, \partial A / \partial T_{d}^{c}=\partial A / \partial T_{d}^{t}$ means that a marginal change in computer use in this activity will not affect student outcomes. For example, both computer-based and traditional instruction methods may have their advantages when it comes to processing and analyzing data, and traditional modes of data processing may often already use such devices as calculators. 
Fourth, there may be cross-effects in that computer instruction in one use substitutes traditional (or computer) instruction in another use, possibly including other uses $r$ that do not lend themselves to computer-assisted instruction at all. In this case, any net effect is possible and the ultimate effect will depend on the relative marginal productivity of time in different modes and uses. Furthermore, as long as there are diminishing returns to time use in any specific activity, the net effect of time used in any specific mode and use may be larger at low use intensity and then decline at some stage. However, fixed setup costs may render specific modes and uses relatively ineffective throughout.

Fifth, the relative marginal productivities of time use may be specific to a subject and grade. In particular, the positive effects of computer-based information about ideas may be more relevant in the explorative stages of a subject matter than in more mature stages. For example, while many of the concepts taught in primary-school math are still very explorative - e.g., $4^{\text {th }}$-graders may look up geometric shapes such as the number of faces, edges, and corners of a cube on the Internet - this may not be as true for high-school math. By contrast, the subject matters taught in the different parts of high-school science may lend themselves particularly well to explorative projects that require looking up new information and ideas on the Internet.

Sixth, because the effect of any time use depends on its own productivity relative to the productivity of the time use it substitutes, any effect also depends on the overall productivity with which teaching time is used in a system. Thus, in systems where teaching time is used quite unproductively to add to students' achievement in any application - as has been shown to be the case for many developing countries (e.g., Pritchett, 2013) - the marginal effect of using computers in any use may be relatively small.

Finally, in addition to the discussed substitution effects, specific time uses may in principle also have an "income effect" in that they increase the effective overall time budget. For example, if a time use replaces otherwise ineffective disrupted classroom time, its net effect will be equal to its marginal product. The same is true if a specific computer-assisted instruction program supplements existing instruction by extending total instruction time per week. Note, however, that this additional instruction time might have more productive alternative uses.

\subsection{Conceptualizing the Mixed Existing Evidence}

This framework of considering the opportunity costs of time in alternative uses can help conceptualize the mixed results in the empirical literature on the effects of using computers in school so far. In fact, most of the studies with rigorous identification strategies in this literature find little or no effect of classroom computers on student learning (see Bulman and Fairlie, 
2014, for a review). This is particularly true for studies that investigate investments in computer hardware and software in general, where some estimates even indicate negative effects (e.g., Angrist and Lavy, 2002; Goolsbee and Guryan, 2006; Leuven et al., 2007; Barrera-Osorio and Linden, 2009; Cristia et al., 2012). But many studies of specific programs of computer-assisted instruction also basically find no effects on student outcomes (e.g., Rouse and Krueger, 2004; Campuzano et al., 2009). In the framework of our model, such null effects of the average application of computers in school are not unexpected if they combine positive and negative underlying effects of specific computer uses. In particular, in many schools there may be no strong mechanism driving teachers toward an optimal allocation of time use in classrooms.

But there are also exceptions of studies indicating positive effects. Barrow, Markman, and Rouse (2009) find positive effects of a popular computer-aided instruction program in three U.S. urban school districts. There are several indications that computers in this particular program may have been put to more effective uses than in general. In particular, the use of computers was clearly defined in this particular program, it explicitly covered issues of classroom management and lesson planning, the program may in fact have increased individualized instruction time, and the districts under study already had experience in using the program and wanted to be evaluated. Machin, McNally, and Silva (2007) find positive effects of additional ICT funding due to a policy change in England. Interestingly, their results indicate that the policy redirected the resources to school districts that were more efficient to begin with, suggesting a potentially more effective choice of time uses. Banerjee et al. (2007) find positive effects of the introduction of a computer-assisted learning program in urban India. In the studied program, half of the program time was additional to standard classroom instruction time so that the policy included an increase in total instruction time. In fact, based on another intervention in India, Linden (2008) shows that the same computer-assisted learning program had a negative effect when implemented in-school to substitute traditional teaching, but had a positive effect when implemented out-of-school to effectively increase the total instruction time budget. The difference in findings of all three exceptions relative to the overall literature thus can be understood within our simple model framework.

However, the key feature of this framework - the relative effectiveness of using computers in different activities - has not been empirically studied so far. The main contribution of our study is to analyze the effects of different computer use activities. In addition, we propose an identification method that allows for causal interpretation of effects of computer use in observational data and study a wide variety of countries that allow for the exploration of heterogeneity and of the external validity of results. 


\section{The TIMSS Data}

\subsection{International Data on Math and Science Achievement}

To estimate the effect of classroom computer use on student achievement, we use data from the 2011 Trends in International Math and Science Study (TIMSS). TIMSS is conducted by the International Association for the Evaluation of Educational Achievement (IEA), an independent international cooperation of national research institutions and government agencies with more than 50 years of experience in international comparative testing. The TIMSS tests emerge from a cooperative venture involving all participating countries to ensure a strong curricular focus of the assessments.

In each participating country, TIMSS draws representative samples of students in $4^{\text {th }}$ grade (usually aged around 10 years) and in $8^{\text {th }}$ grade (usually aged around 14 years). The two-stage sampling design first randomly samples schools out of all schools in a country with sampling probabilities proportional to school size and then randomly samples one or more classrooms in each sampled school. ${ }^{7}$ Our main focus is on $8^{\text {th }}$ grade because the use of classroom computers may require a certain degree of maturity, making it more effective in post-elementary school settings. While basic computer skills can be assumed for $8^{\text {th }}$-grade students, they are a potential limitation to using computers in $4^{\text {th }}$ grade. Students in $8^{\text {th }}$ grade may also use computers in a more systematic way and be able to perform more specific tasks such as processing data from experiments in science classes. To investigate grade specificities, we also analyze the $4^{\text {th }}$-grade sample which has the advantage of allowing us to perform within-teacher analyses because many $4^{\text {th }}$-grade students are taught by the same teacher in both subjects.

An important feature for our identification strategy is that TIMSS measures achievement in two subjects, math and science. To ensure a clear matching between measured science achievement and current teacher and computer use information, we restrict our analysis to students in schools that teach integrated science courses, that is, students enrolled in science as a single subject taught by a single teacher. ${ }^{8}$ This leaves out countries where students are taught science as separate subjects, usually by different teachers with different uses of classroom time (e.g., in separate biology, chemistry, physics, and geography classes, only a subset of which is usually taught in any specific grade). Our sample includes 155,948 students in 30 countries in $8^{\text {th }}$ grade and 245,482 students in 53 countries in $4^{\text {th }}$ grade. Throughout the analysis, we

\footnotetext{
${ }^{7}$ Students with disabilities and students who are unable to read or speak the national test language are not sampled in TIMSS.

${ }^{8}$ Furthermore, our sample does not include students with missing information on either math or science achievement or on any of the computer use variables. The $8^{\text {th }}$-grade sample excludes students aged below 13 years.
} 
standardize test scores to mean 0 and standard deviation 1 in this estimation sample. ${ }^{9}$ In standardization and estimation, students are weighted by their national sampling probability and each country receives the same weight in the total estimation.

\subsection{Data on Computer Use and other Background Information}

Another key for our analysis is that TIMSS administers extensive teacher background questionnaires for both math and science teachers who provide, among others, detailed information on computer use intensities in different activities. Specifically, apart from reporting whether students in their class have computers available to use during their respective math or science lessons, teachers report how often they have the students do the following computer activities during their respective math or science lessons: "look up ideas and information," "practice skills and procedures," and "process and analyze data" (the third category not being available in $4^{\text {th }}$ grade). ${ }^{10}$ Use intensity is reported in four categories: "never or almost never," "once or twice a month," "once or twice a week," and "every or almost every day." In our main analyses, we scale computer use in each activity from 0 (no computer available) to 4 (use (almost) every day). In robustness analyses, we show that results do not depend on the linearization of the categorical information but also emerge in specifications that use different indicator variables of computer-use intensity. For direct comparability of movements within the distribution of usage intensity in different activities, we normalize use intensity in each activity to mean 0 and standard deviation 1 in the regression analyses. For comparison with the literature that does not distinguish between different computer uses, we also combine the three uses into a single index of combined computer use by adding up the separate standardized measures and normalizing the sum again. ${ }^{11}$

Table 1 shows descriptive statistics for the different computer use measures. Among all $8^{\text {th }}$-grade students, 32 percent have computers available in their math classrooms and 40 percent in science. Use intensities vary both between subjects and between activities. In general, computers are used more frequently in science than in math. For example, 21 percent of students use computers to look up ideas and information at least once a month in math, whereas 34 percent do so in science. The difference is less pronounced in practicing skills and procedures, where again 21 percent use computers at least once a month in math but 28 percent

\footnotetext{
${ }^{9}$ In our analysis, we use the first plausible value of the math and science scores, respectively.

${ }^{10}$ Math teachers also report on computer use to "explore mathematics principles and concepts" and science teachers to "do scientific procedures or experiments" and to "study natural phenomena through simulations." Since these activities do not have respective counterparts in the other subject, we do not use them in our analysis.

${ }^{11}$ Results are virtually identical when not standardizing the separate measures before adding them up.
} 
in science. The different types of computer uses are strongly correlated within subjects, but not very strongly across subjects: within-subject correlations range from 0.91 to 0.93 , between-subjects correlations from 0.26 to 0.29 (see Table A1 in the appendix). Computer availability and usage varies substantially across countries, with the highest use intensities in Australia and the lowest in Honduras (see Table A2 in the appendix). For our identification strategy, it is important that there is within-student variation in computer use across subjects. The descriptive statistics show that this is indeed the case: On average across countries, 45 percent of students have a different intensity of computer use in math than in science to look up ideas and information, and 44 percent in the other two activities.

Apart from the computer use information, the extensive teacher background questionnaires also provide a wealth of additional subject-specific information on teachers and their teaching methods. For example, teachers report on their education, their satisfaction with the profession, their interaction with other teachers, their participation in general and computer-related professional development, their homework policies, as well as specifics of their teaching methods (see Table A3 in the appendix for details). Such comprehensive teacher information will prove useful when testing whether performance-relevant variation in computer use is associated with other teacher characteristics or chosen teaching methods. Furthermore, TIMSS provides rich subject-invariant information on students' individual and family background (including their computer use at home) from questionnaires answered by students and on their schools' background from questionnaires answered by school principals. ${ }^{12}$

In our analysis of heterogeneity across countries, we add country-level data from additional sources. For general country characteristics such as GNP per capita and population size, we use 2010 data from the World Bank. The number of speakers of different languages comes from the Ethnologue 2013. The World Telecommunication/ICT Indicators Database, published by the U.N. agency International Telecommunication Union, provides information on the share of people using the Internet and the number of broadband Internet subscriptions per capita.

\section{Empirical Model}

\subsection{The Basic Education Production Function}

To estimate the effect of computer use on student achievement, we use a linearized subject-specific version of equation (1) above:

\footnotetext{
12 In our regression analyses, we impute missing values in the control variables by the school mean or, if not available, by the country mean.
} 


$$
A_{s i}=T_{u, s i}^{c} \beta_{s}+X_{i} \alpha+S_{s i} \gamma_{s}+\mu_{i}+\tau_{t}+\varepsilon_{s i} \quad \forall s \in(m, n)
$$

where achievement $A$ of student $i$ in subject $s$ - either math $m$ or science $n$-is a function of the classroom time $T$ spent using computers $c$ in different uses $u$, as well as vectors of out-of-school input factors $X$ such as student and family background and additional school input factors $S$ including subject-specific information on teachers and their teaching methods (see Table A3 in the appendix for a list of all background control variables). The error term has a student-specific component $\mu_{i}$, a teacher-specific component $\tau_{t}$, and a student-subject-specific component $\varepsilon_{s i}$.

Based on our conceptual framework, we expect the coefficients of interest $\beta_{s}$ to be specific to the respective subject $s$. The effect of using computers to look up ideas and information may, for example, depend on the explorative nature of the subject matter taught. Thus, computers are likely to be used differently in math than in science, and exert different effects on outcomes, because of the suitability of subject material for computer-based instruction or the different availability of software and teaching materials. ${ }^{13}$

A large number of early studies have estimated some version of equation (2) applying OLS estimation to observational data (Bulman and Fairlie, 2014). ${ }^{14}$ However, the use of computers in the classroom is unlikely to be randomly assigned conditional on usually observed factors, leading to bias in cross-sectional estimates from selection and omitted variables. For example, schools in richer areas might find it easier to attract money from parents or local firms for new computer equipment, students with specific abilities may select into schools and classrooms that use computers, and teachers may choose to use computers only with high-performing classes. Given limits to being able to observe all relevant family-background, ability, and other inputs in the education production function, computer use is unlikely to be exogenous in the model. As a consequence, the student-specific error term $\mu_{i}$ is likely to be correlated with classroom computer use, precluding causal interpretation of cross-sectional estimates.

\subsection{Within-Student Between-Subject Identification: Correlated Random Effects Model}

To avoid such sources of bias from nonrandom selection of students into specific schools or classrooms, we identify from the between-subject variation in computer use and achievement

\footnotetext{
${ }^{13}$ Our experience from visiting a leading German school in extensive computer use is that in every subject teachers and students use computers slightly differently. In math, for example, many teachers in Germany use a specific software package that allows students to graphically explore different fields of geometry, algebra, calculus, and statistics. In science, students are more likely to use the Internet for research on specific topics and to work on projects with other students.

${ }^{14}$ For example, Fuchs and Woessmann (2004) have used international student achievement tests before to explore computer use in a multivariate setting, indicating the sensitivity of cross-sectional estimates to the richness of the set of control variables included.
} 
within each student available in our data. This approach builds on other recent studies that similarly exploit such within-student between-subject variation to hold subject-invariant unobserved school and student characteristics constant when identifying effects of other teacher and teaching characteristics (e.g., Dee 2005, 2007; Clotfelter, Ladd and Vigdor, 2010; Schwerdt and Wuppermann, 2011; Lavy, 2014). However, their student fixed effects models assume that the treatment effect is the same across subjects.

To be able to identify the kind of subject-specific effects discussed above, we estimate a correlated random effects model that generalizes the fixed effects model to subject-specific effects (see Metzler and Woessmann, 2013). In particular, as suggested by Chamberlain (1982), we model the correlation that might exist between the student-specific error component $\mu_{i}$ and all observed input factors in the two subject-specific equations (2) in a very general way:

$$
\mu_{i}=T_{u, m i}^{c} \eta_{m}+T_{u, n i}^{c} \eta_{n}+X_{i} \varphi+S_{m i} \chi_{m}+S_{n i} \chi_{n}+\omega_{i}
$$

where by construction the residual $\omega_{i}$ is uncorrelated with the observed variables in $T_{i}, X_{i}$, and $S_{i}$. Note that we allow the parameters $\eta$ and $\chi$ to take different values in the two subjects.

Substituting equation (3) into the subject-specific equations (2) we obtain:

$$
A_{s i}=T_{u, s i}^{c}\left(\beta_{s}+\eta_{s}\right)+T_{u,-s i}^{c} \eta_{-s}+X_{i}(\alpha+\varphi)+S_{s i}\left(\gamma_{s}+\chi_{s}\right)+S_{-s i} \chi_{-s}+\tau_{t}+\varepsilon_{s i}^{\prime} \quad \forall s
$$

where $-s$ refers to the respective other subject (i.e., science in the math equation and vice versa) and $\varepsilon_{s i}^{\prime}=\varepsilon_{s i}+\omega_{i}$. Note that all subject-specific controls enter both the equation for math and the equation for science. That is, math achievement is regressed on computer use in math and on computer use in science (equivalently for science achievement), so that science computer use is held constant when estimating the coefficient on math computer use (and vice versa).

As is evident from equations (4), the coefficient on $T_{u, m i}^{c}$ in the science equation $\left(\eta_{s}\right)$ captures the extent to which the coefficient on $T_{u, m i}^{c}$ in the math equation is biased away from the actual effect $\beta_{m}$ of math computer use on math achievement.

The two subject-specific equations (4) comprise a correlated random effects model that can be jointly estimated by seemingly unrelated regressions. Let us denote the coefficient on the own-subject computer use variables $T_{u, s i}^{c}$ by $\hat{\theta}_{s}^{s}$ and the coefficient on the other-subject computer use variables $T_{u,-s i}^{c}$ by $\hat{\theta}_{-s}^{s}$. Then, the coefficients of interest $\beta_{s}$ implied in this model are given straightforwardly by 


$$
\hat{\beta}_{s}=\hat{\theta}_{s}^{s}-\hat{\theta}_{s}^{-s} \quad \forall s
$$

That is, the effect of interest in math can be estimated by the difference between the coefficient on math computer use in the math equation and the coefficient on math computer use in the science equation (and vice versa for science).

Note that this correlated random effects model nests the more traditional fixed-effects model as a special case (see Ashenfelter and Zimmerman, 1997). To see this, assume $\beta_{m}=\beta_{n}$ and $\eta_{m}=\eta_{n}$ (as well as $\gamma_{m}=\gamma_{n}$ and $\chi_{m}=\chi_{n}$ ), which are the identifying assumptions implicit in the fixed-effects model. Applying these assumptions to equations (4) and taking the difference of the two subject-specific equations, we obtain

$$
\Delta A_{i}=\Delta T_{u, i}^{c} \beta+\Delta S_{i} \gamma+\varepsilon_{i}^{\prime \prime}
$$

where $\Delta$ refers to the between-subject difference in each variable and $\varepsilon_{i}^{\prime \prime}=\Delta \varepsilon_{i}^{\prime}$. This is the well-known first-difference representation of the traditional fixed-effects model.

In our correlated random effects model, we can test the identifying assumptions implicit in the fixed-effects model. In particular, given equation (5) above, $\hat{\theta}_{m}^{m}-\hat{\theta}_{m}^{n}=\hat{\theta}_{n}^{n}-\hat{\theta}_{n}^{m}$ provides a test of $\beta_{m}=\beta_{n}$ and $\hat{\theta}_{m}^{n}=\hat{\theta}_{n}^{m}$ provides a test of $\eta_{m}=\eta_{n}$. As these assumptions are generally rejected in our empirical application - in particular, computer use often tends to have subject-specific effects - we generally stick with the more general correlated random effects model and show results of a traditional fixed-effects model only in passing.

\subsection{Teacher Characteristics, Teaching Methods, and Within-Teacher Identification}

A remaining potential concern with equations (4) is that other achievement-relevant teacher characteristics might be correlated with the use of computers in the classroom. For example, if young teachers were both more likely to use computers and more motivated, estimating the model without taking teacher age into account would lead to omitted variable bias. The same would be true if teachers who use computers in the classroom generally assigned more homework. To mitigate such potential bias, we make use of the rich subject-specific teacher information available in the TIMSS data (see Table A3 in the appendix) to control extensively for teacher characteristics and teaching methods in the school input vector $S$.

Note that it is unclear to what extent this vector should include controls for teaching methods. To the extent that, for example, relating lessons to students' daily lives - one teaching-method control available in TIMSS - is a feature that a computer-using teacher would 
have also employed without the availability of computers, it should be held constant in the model. To the extent, however, that using computers facilitates relating lessons to students' daily lives, this teaching practice reflects a channel of the computer-use effect that should not be held constant in the model.

Going beyond controlling for teacher characteristics, we can exploit the fact that most primary-school students are taught by the same teacher in math and in science. By restricting the $4^{\text {th }}$-grade sample to students for which this is the case, $\tau_{t}$ effectively drops out of equations (4) and the estimates are no longer biased by subject-invariant teacher traits. In addition, we can condition on any observed difference in teaching methods of the same teacher in the two subjects. Comparing results from the same-teacher sample to the full sample will provide an indication of the relevance of remaining unobserved teacher effects in our model.

\section{Eighth-Grade Results}

\subsection{Cross-Sectional Regressions}

As a benchmark for previous studies, we start with conventional cross-sectional regressions, estimated separately in math and in science. Table 2 shows results of least-squares estimations in the $8^{\text {th }}$-grade TIMSS sample with different sets of control variables. ${ }^{15}$ In our main specification, shown in the top panel, the three measures of computer use in different activities enter jointly in the model. For comparison with the existing literature, the bottom panel shows a specification with the index of combined computer use. The combined computer use variable is positively associated with student achievement in both math and science, reaching statistical significance in science throughout and in math once teaching-method controls are included. ${ }^{16}$

But this overall association hides significant differences between different uses of computers: In the specification with separate measures of computer use, achievement is significantly positively associated with the intensity of using computers to process and analyze data, but negatively with using computers to practice skills and procedures (although losing significance in science once teacher controls are included), and not significantly with using computers to look up ideas and information.

This pattern does not change much with the specific set of control variables included in the models. The models in the first two columns control just for basic controls which include student characteristics such as gender, age, and migration status; family-background

\footnotetext{
15 Throughout the paper, we cluster standard errors at the classroom level. In the SUR models, standard errors are estimated by maximum likelihood.

16 The simple correlations of combined computer use with achievement are also significantly positive.
} 
characteristics such as parental education, books at home, and language spoken at home; and school characteristics such as neighborhood location and material endowment (see Table A3 in the appendix for a complete list of control variables). The models in columns 3 and 4 add teacher controls which include both classroom characteristics such as class size, instruction time, and class composition and teacher characteristics such as gender, age, education, professional development, job satisfaction, and interaction with other teachers. Note that the baseline controls also include measures of computer proficiency of students and teachers, namely whether students have computers and Internet connections at home and how often they use computers at home, as well as whether the teacher participated in professional development in integrating information technology into math or science, respectively, in the past two years. The models in columns 5 and 6 add teaching-method controls such as frequency of discussing and correcting homework, use of textbooks, means of monitoring progress, use of questioning to elicit explanations, and relation of lessons to daily life.

In the final columns of Table 2, the same two subject-specific equations are estimated by seemingly unrelated regressions (SUR), which in the case where error terms are correlated across the equations - for example, because of a student having a bad testing day - yields more efficient estimators. Note that the teacher controls vary across subjects if a student has different teachers in the two subjects, and the teaching-method controls are subject-specific throughout. The main difference to the OLS models is that the coefficient on using computers to look up ideas and information becomes significantly positive in science. Still, for the reasons discussed above, the OLS and SUR coefficients are likely to suffer from selection bias.

\subsection{Correlated Random Effects Models}

To circumvent bias from the non-random selection of students into schools and classes with different computer uses, we identify the effect of computer use on student achievement from within-student between-subject variation in computer use. In Table 3, we start with the traditional fixed effects model of equation (6). Quite independent of the different sets of controls included in the model, results suggest that using classroom computers to look up ideas and information has a positive effect on student achievement, whereas using classroom computers to practice skills and procedures has a negative effect. Using classroom computers to process and analyze data does not have a significant effect. In the conventional fixed effects model, the combined effect of computer use indicates a very small positive effect. Note that this pattern of results differs markedly from the cross-sectional estimates, highlighting the importance of addressing selection issues. 
Table 4 reports results of the correlated random effects models of equations (4) that relax the assumption that effects are the same in both subjects. It shows the estimated effects of computer use on student achievement $\beta_{s}$ in each subject implied in this model as given by equations (5). From the pertinent $\chi^{2}$ tests, it becomes evident that the significant results are restricted to science, whereas results do not reach statistical significance in math. In fact, the table also shows that the difference in the estimated $\beta$ coefficients between math and science is statistically significant in most cases, indicating that the effects of computer use in the classroom can be subject-specific. Similarly, some of the estimated selection terms $\eta$ differ significantly between the two subjects. ${ }^{17}$ This speaks against the assumption of subjectinvariant effects implicit in traditional fixed effects model.

Consistent with the opposing effects of different computer uses in science, the combined effect of computer use does not differ significantly from zero in the correlated random effects models (except for a negative effect in math with basic and teacher controls, but no teachingmethod controls). Such null effects are in line with most findings in the literature. Together with the use-specific results, this suggests that by averaging over different computer uses, the literature so far may have missed important effects of using computers in specific applications.

In terms of effect size, the estimates suggest that a one-standard-deviation increase in the intensity of using classroom computers to look up ideas and information increases science achievement by 3.3-4.1 percent of a standard deviation (depending on whether teaching methods are controlled for or not), whereas a one-standard-deviation increase in the intensity of using classroom computers to practice skills and procedures reduces science achievement by 2.0-3.1 percent of a standard deviation. Put differently, going from no computer use at all to daily use of computers in the classroom increases science achievement by 10-13 percent of a standard deviation if used for looking up ideas and information, but decreases science achievement by 7-11 percent of a standard deviation if used to practice skills and procedures.

A possible source of remaining bias in the between-subject identification would be if teachers who use computers differently also differ in other characteristics and behaviors that are relevant for student outcomes. If this was a main issue, results should differ by whether the particularly rich set of controls for teacher characteristics and teaching methods available in the TIMSS data are included in the model or not. However, as is evident from a comparison of columns 2 and 3 of Table 4, qualitative results are unaffected by their inclusion, and they also

\footnotetext{
${ }^{17}$ Since the restriction of $\eta_{m}=\eta_{n}$ for single variables results in only minor efficiency gains for our estimations, we abstain from applying such restrictions here.
} 
do not substantially affect the magnitude of the estimated effects of computer use. This pattern suggests that substantial remaining bias in the between-subject model is unlikely.

Whether or not one should control for teaching methods in our model is in fact an open question. To the extent that features such as encouraging students to improve performance, using a workbook as the basis for instruction, monitoring completed homework, or emphasizing tests for progress monitoring capture differences across teachers that are exogenous to computer use, they should be held constant. But if they are endogenous to computer use in that their application is facilitated by using computers, they are an outcome of computer use and thus constitute a channel of the computer-use effect that should not be held constant. In the end, though, controlling for teaching methods makes relatively little difference for the substantive results. We thus use the more conservative model that includes teaching-method controls as our baseline model in the remainder of the paper.

Results also do not depend on the linearized version of the computer-use variables. For example, one may argue that in terms of achievement effects, using a computer almost never or at most twice a month are not very different from not having a computer available at all. Thus, computer use could alternatively be measured by an indicator of using computers at least once per week for the respective activity. With such a measure, both the positive effect of using computers to look up ideas and information and the negative effect of using computers to practice skills and procedures emerge just as in our main specification (see Table A4 in the appendix). Similarly, results show for an indicator of using computers at least once per month.

\section{Fourth-Grade Results}

\subsection{Full Sample}

We have focused our main analysis on the $8^{\text {th }}$-grade sample where computer use might be expected to be more mature and systematic. Still, computer use is quite common also in primary school. In fact, 39 percent of $4^{\text {th }}$-graders in the TIMSS dataset have a computer available in their math classroom and 45 percent in science (see Table 1). That is, computer availability in the $4^{\text {th }}$-grade TIMSS sample is not very different from $8^{\text {th }}$ grade. ${ }^{18}$ Similarly, the different intensities to which computers are used do not differ markedly between $4^{\text {th }}$ and $8^{\text {th }}$ grade. In $4^{\text {th }}$ grade, computer use to look up ideas and information is most intensive in science (39 percent use at least once a month vs. 25 percent in math), whereas computer use to practice skills and

\footnotetext{
${ }^{18}$ While the participating countries differ in the respective samples in Table 1 , the pattern is the same in the 22 countries that participated both in $4^{\text {th }}$ grade and in $8^{\text {th }}$ grade. In these countries, computer availability in $4^{\text {th }}$ grade is 40 percent in math and 48 percent in science, and in $8^{\text {th }}$ grade it is 35 percent in math and 45 percent in science.
} 
procedures is most intensive in math ( 32 percent vs. 30 percent in science). Thus, in math computers are in fact most often used to practice skills and procedures, whereas in science they are most often used to look up ideas and information. Again, there is substantial variation in computer use across countries, as well as within students across subjects (see Table A5).

Table 5 shows the results of our correlated random effects models that identify the effect of computer use on student achievement from within-student between-subject variation in $4^{\text {th }}$ grade. The general pattern of findings is the same as in $8^{\text {th }}$ grade: Student achievement increases with the use of computers to look up ideas and information but decreases with the use of computers to practice skills and procedures. Irrespective of whether teacher and teaching-methods are controlled for or not, ${ }^{19}$ the negative effect of using computers to practice skills and procedures is significant in both subjects, whereas the positive effect of using computers to look up ideas and information is significant only in math. In the full sample, the specific computer use effects do not differ significantly across the two subjects. Thus, when restricting the effects to be the same across subjects, both the positive effect of using computers to look up ideas and information and the negative effect of using computers to practice skills and procedures clearly come out in the fixed effects model shown in Table 3.

In the correlated random effects models, the combined effect of computer use in $4^{\text {th }}$ grade is insignificantly positive in math, but significantly negative in science. In the fixed effects model, the negative effect tends to dominate, reaching marginal significance in the model with teaching-method controls. However, the between-subject difference of the combined effect is statistically significant, speaking against the restrictions implied by the fixed effects model.

While the general pattern of opposing effects of different computer uses is the same in the two grades, note that there are also interesting grade specifics: In $8^{\text {th }}$ grade, the significant effects are restricted to science rather than math. By contrast, in $4^{\text {th }}$ grade they are most pronounced in math. One possible explanation for this pattern is that the subject matters taught in math in $4^{\text {th }}$ grade have a larger explorative component than in $8^{\text {th }}$ grade, so that the use of computers to look up ideas and information yields stronger positive effects in the earlier grade.

The effect sizes suggest that in $4^{\text {th }}$ grade, a one-standard-deviation increase in the intensity of computer use to look up ideas and information increases student achievement by 1.9-2.3 percent of a standard deviation (depending on the included controls) in math (and an insignificant 0.8-1.0 percent in science). By contrast, a one-standard-deviation increase in the intensity of computer use to practice skills and procedures decreases achievement by 1.2-1.9

\footnotetext{
${ }^{19}$ See Table A6 in the appendix for descriptive statistics of the control variables in $4^{\text {th }}$ grade.
} 
percent of a standard deviation in math and by 2.3-2.8 percent in science. Put differently, going from no to daily computer use raises math achievement by 7-8 percent of a standard deviation when used to look up ideas and information but lowers it by 4-6 percent of a standard deviation when used to practice skills and procedures (8-10 percent in science). Overall, effect sizes are somewhat smaller in $4^{\text {th }}$ grade than in $8^{\text {th }}$ grade.

\subsection{Same-Teacher Sample: Identification from Within-Teacher Variation}

A particular advantage of the $4^{\text {th }}$-grade sample is that - in contrast to the $8^{\text {th }}$-grade sample many elementary-school students are taught by the same teacher in math and science. In fact, 65 percent of students in the TIMSS $4^{\text {th }}$-grade sample have the same teacher in both subjects. Restricting the analysis to these students allows us to estimate the same model in a withinteacher specification. In this specification, estimates of computer use cannot be biased by any unobserved subject-invariant teacher characteristics or selection of teachers into classrooms.

Results in the right-hand panel of Table 5 indicate that the general pattern of results is very similar in this same-teacher sample. While the effect of using computers to practice skills and procedures loses significance in science, in math both the positive effect of using computers to look up ideas and information and the negative effect of using computers to practice skills and procedures get stronger when the sample is restricted to students taught by the same teacher in the two subjects. The combined effect of computer use is significantly positive in math and insignificant in science in the same-teacher sample. Most of the estimated effects in this sample differ significantly between the two subjects.

The fact that qualitative results do not differ between the full-sample model and the same-teacher model indicates that the former are not driven by unobserved subject-invariant characteristics of teachers. Furthermore, results of the same-teacher specification are quite impervious to conditioning on subject-specific teaching methods, increasing confidence that the estimates are not substantively biased by subject-specific features of teaching methods.

\section{Heterogeneity in the Effects of Computer Use}

\subsection{Effects for Different Student Subgroups}

It is often argued that the effects of using computers may be different depending on students' gender, achievement level, socioeconomic status, or computer familiarity. For example, on the one hand the use of computers might make it easier to adjust the level of difficulty and learning speed to the capabilities of disadvantaged students (in terms of ability or SES) and to repeat learning materials as needed. On the other hand, the use of computers might 
require complementary skills such as basic cognitive knowledge or critical thinking, as well as proactivity, self-discipline, and autonomy which might be less pronounced among disadvantaged students. Furthermore, one might expect that students who are already familiar with using computers might be better equipped to benefit from computer use in the classroom.

To test such effect heterogeneity, we divide the sample in two subsamples along each of the four dimensions gender, achievement level, socioeconomic status, and computer familiarity. We measure students' achievement levels by the average of their math and science test score (note that identification in our model comes just from the between-subject difference in achievement). The number of books in the students' home lends itself as a measure of socioeconomic background in a cross-country setting. Computer familiarity is captured by the frequency with which students use computers at home. For each of these measures, we subdivide the sample by whether a student is above/at or below the median within his or her country. ${ }^{20}$ We perform the subsample analyses both in $8^{\text {th }}$ grade and in $4^{\text {th }}$ grade, where we stick to the same-teacher sample.

Table 6 reports results separately by gender. As is evident, there is not much heterogeneity in the effects of various computer uses along this dimension: Both girls and boys benefit from the use of computers to look up ideas and information and suffer from the use of computers to practice skills and procedures, and the effect is restricted to science in $8^{\text {th }}$ grade and to math in $4^{\text {th }}$ grade. While the negative effect of using computers for practicing skills and procedures is shy of statistical significance for boys in $8^{\text {th }}$ grade, the $8^{\text {th }}$-grade male effects are actually larger and highly significant when the sample is restricted to OECD countries (not shown).

The same pattern of opposite use-specific effects of classroom computers also emerges in both subsamples of students achieving above and below their respective country medians (Table 7). In $8^{\text {th }}$ grade, the negative effect of using computers to practice skills and procedures does not reach statistical significance for high-achieving students. However, the high-achieving students suffer significantly from using computers to process and analyze data more frequently, which is not true for low-achieving students. In $4^{\text {th }}$ grade, both effects are larger for high-achieving than for low-achieving students, and the negative effect of using computers to practice skills and procedures is small and statistically insignificant for low-achieving students.

Table 8 reports results for subsamples of students by socioeconomic background. In both grades, the effects tend to be stronger for students with high socioeconomic background than

\footnotetext{
${ }^{20}$ The actual number of student observations can differ between the above/at-median subsample and the below-median subsample because students are weighted by their sampling weights in calculating the medians and because books and computer use at home are measured in five and four categories, respectively.
} 
for students with low socioeconomic background. While the effects for students with relatively few books at home are shy of statistical significance in the $8^{\text {th }}$-grade sample of all participating countries, these effects are in fact statistically significant in the $8^{\text {th }}$-grade sample of OECD countries (not shown). Thus, while both positive and negative effects of the different computer uses also exist for low-SES students, both tend to be smaller than for high-SES students.

Interestingly, though, the estimated effects do not differ markedly by whether students regularly use a computer at home or not (see Table A7 in the appendix). Thus, computer use at home does not appear to be a crucial prerequisite for profiting - or suffering - from the respective computer uses in the classroom.

Overall, when looking at effect heterogeneity for students by gender, achievement level, family background, and computer familiarity, consistent differences appear to exist only along the family-background dimension. While computer use affects achievement of students with both high and low socioeconomic status, effects tend to be larger for high-SES students. ${ }^{21}$

\subsection{Effects in Different Country Subgroups}

The effects of computer use may also be expected to differ across countries. As argued in our conceptual framework, effects may be less pronounced in developing countries because of overall lower levels of effectiveness in teaching. In addition, effects may depend on the availability of instructional material for computer-assisted instruction or on the pervasiveness of Internet access and use in a country. To test for heterogeneous effects across countries, we subdivide our country sample into OECD and non-OECD countries, as well as countries above (or equal) and below the sample median of GNP per capita and of other country features.

Table 9 presents results by countries' level of development. In both $8^{\text {th }}$ and $4^{\text {th }}$ grade, both the positive effect of using computers to look up ideas and information and the negative effect of using computers to practice skills and procedures are confined to the sample of OECD countries. In the non-OECD countries, only the positive effect of using computers to look up ideas and information in $4^{\text {th }}$ grade reaches marginal significance. Similarly, in $8^{\text {th }}$ grade the significant effects are fully confined to the subsample of countries with above-median per-capita GNP (see Table A8 in the appendix). Only in $4^{\text {th }}$ grade are the effects significant in both subsamples of above-median and below-median per-capita GNP, despite the fact that the median GNP is the same in both grade samples.

\footnotetext{
${ }^{21}$ We also experimented with heterogeneous effects by teacher characteristics and teaching methods. The subsamples are best defined in the same-teacher sample in $4^{\text {th }}$ grade. We find the standard pattern of computer-use effects both for young and old teachers, female and male teachers, teachers with high and low education, and teachers who do or do not frequently relate the lesson to students' daily lives.
} 
When dividing the sample by other country features, we do not find clear patterns of additional effect heterogeneity (not shown). This is true when subdividing the sample by the availability of broadband subscriptions and of Internet use in a country, as well as by the size of the country population or by the world population that speaks a country's main language. The first two measures are meant to proxy for the Internet familiarity of the country's population, the other two measures for the size of the market and thus the availability of appropriate software and digital teaching materials. The general absence of differences in the effects of computer use along these lines is consistent with the lack of heterogeneity by individual computer use at home that we found above. This is despite the fact that most of these features are clearly correlated with the frequency of computer use in schools across countries in the TIMSS data. We also explored subsamples by other country characteristics, including educational spending, the per-capita number of computers, age structure, and average use of computers in schools, not finding any clear pattern of additional country heterogeneity.

Overall, both positive and negative effects of different kinds of computer use seem to be confined to more developed countries, in particular in $8^{\text {th }}$ grade. By contrast, computer use does not exert strong effects in less developed countries. There are no obvious other patterns of country heterogeneity.

\section{Conclusion}

In the public debate as well as in the policy arena, there is considerable enthusiasm about the potential of using new technologies in classrooms. While the production process of most goods has changed dramatically over the past century, until recently the physical appearance of classrooms has not changed much since chalkboards were introduced in Prussian classrooms in the late $18^{\text {th }}$ century (Konrad, 2007). However, the arrival of computers, tablets, and the Internet has challenged many traditional teaching practices and is supposed to change the educational production technology in schools dramatically. Following the call of such big hopes, policymakers and educators all over the world rush to bring computers into every classroom. Such enthusiasm and costly investment is hard to reconcile with the available evidence that computer use in schools has little if any effect on student achievement.

We suggest that the overall null effect of using computers in schools is a combination of relatively productive and unproductive uses of computers. Depending on the opportunity cost of the time used in computer-assisted instruction - whether it replaces less or more productive traditional uses of teaching time - computer use can have a positive or negative net effect on what students learn. Specifically, our empirical results suggest that classroom computers are 
beneficial to student achievement when used to look up ideas and information but detrimental when used to practice skills and procedures. These opposite effects of different computer use activities offset each other, with a combined effect of computer use in schools that is generally close to zero. In $8^{\text {th }}$ grade, the opposing use-specific effects are most pronounced in science, whereas in $4^{\text {th }}$ grade they are most pronounced in math. Effects prove quite general across different subgroups of students including students with little computer experience at home, although they are somewhat smaller for students from low socioeconomic background. Effects are mostly confined to developed countries, whereas we find little evidence for significant (positive or negative) effects of computer use in less developed countries. Our empirical model identifies these effects of computer use from within-student between-subject variation.

Our findings emphasize that in evaluating any educational innovation, it is important to consider its costs. An important part of these costs is the opportunity cost of classroom time that a specific intervention takes up. Using computers for activities that do not improve student learning takes away time from activities that are potentially more effective to this end. This is true for the use of computers compared to other teaching methods such as traditional lecture-style teaching or individual learning, but also for more and less effective activities on the computer. For example, while we do not find any significant effect of using computers to process and analyze data, using the same classroom time to use computers to look up ideas and information would improve overall outcomes according to our estimates.

Beyond the opportunity cost of time, equipping classrooms with computers, software, and broadband infrastructure, maintaining these facilities and keeping them up to date, and training teachers to use them also entails substantial financial costs (which likely vary across countries, complicating cost-benefit analyses). Thus, while we find that using computers to look up ideas and information would improve student achievement, maximum effect sizes of 10-13 percent of a standard deviation are moderate enough to raise cost effectiveness concerns relative to other educational interventions. At the same time, our evidence is confined to effects of computer use on student achievement in math and science. To the extent that computer use in schools furthers other valued outcomes such as the acquisition of computer skills, such additional benefits must be taken into account in an overall cost-benefit assessment of computer-assisted classroom instruction. In any case, our results suggest a clear focus on the specific types of activities to which computers are put to use. 


\section{References}

Angrist, Joshua D., and Victor Lavy. 2002. "New evidence on classroom computers and pupil learning." Economic Journal 112 (482): 735-765.

Ashenfelter, Orley C., and David J. Zimmerman. 1997. "Estimates of the returns to schooling from sibling data: Fathers, sons, and brothers." Review of Economics and Statistics 79 (1): 1-9.

Autor, David H., Frank Levy, and Richard J. Murnane. 2003. "The skill content of recent technological change: An empirical exploration." Quarterly Journal of Economics 118 (4): $1279-1333$.

Banerjee, Abhijit V., Shawn Cole, Esther Duflo, and Leigh Linden. 2007. "Remedying education: Evidence from two randomized experiments in India." Quarterly Journal of Economics 122 (3): 1235-1265.

Barrera-Osorio, Felipe, and Leigh L. Linden. 2009. "The use and misuse of computers in education: Evidence from a randomized experiment in Colombia." Policy Research Working Paper 4836. Washington, DC: World Bank.

Barrow, Lisa, Lisa Markman, and Cecilia Elena Rouse. 2009. “Technology's edge: The educational benefits of computer-aided instruction." American Economic Journal: Economic Policy 1 (1): 52-74.

Bauernschuster, Stefan, Oliver Falck, and Ludger Woessmann. 2014. "Surfing alone? The Internet and social capital: Evidence from an unforeseeable technological mistake." Journal of Public Economics 117: 73-89.

Bhuller, Manudeep, Tarjei Havnes, Edwin Leuven, and Magne Mogstad. 2013. "Broadband Internet: An information superhighway to sex crime?" Review of Economic Studies 80 (4): $1237-1266$.

Bowen, William G., Matthew M. Chingos, Kelly A. Lack, and Thomas I. Nygren. 2014. "Interactive learning online at public universities: Evidence from a six-campus randomized trial." Journal of Policy Analysis and Management 33 (1): 94-111.

Bulman, George, and Robert W. Fairlie. 2014. "Technology and education: The effects of computers, the Internet and computer assisted instruction on educational outcomes. Manuscript prepared for the Handbook of the Economics of Education, Vol. 5, edited by Eric A. Hanushek, Steven Machin, and Ludger Woessmann. Amsterdam: North Holland.

Campuzano, Larissa, Mark Dynarski, Roberto Agodini, and Kristina Rall. 2009. "Effectiveness of reading and mathematics software products: Findings from two student cohorts." NCEE 
2009-4041. Report prepared by Mathematica Policy Research, Inc. Washington, DC: U.S. Department of Education.

Chamberlain, Gary. 1982. "Multivariate regression models for panel data." Journal of Econometrics 18 (1): 5-46.

Chingos, Matthew M., and Guido Schwerdt. 2014. "Virtual schooling and student learning: Evidence from the Florida Virtual School.” Program on Education Policy and Governance Working Paper PEPG 14-02. Cambridge, MA: Harvard Kennedy School.

Clotfelter, Charles T., Helen F. Ladd, and Jacob L. Vigdor. 2010. "Teacher credentials and student achievement in high school: A cross-subject analysis with student fixed effects." Journal of Human Resources 45 (3): 655-681.

Cristia, Julián P., Pablo Ibarraran, Santiago Cueto, Ana Santiago, and Eugenio Severín. 2012. "Technology and child development: Evidence from the One Laptop per Child Program." IDB Working Paper 304. Washington, DC: Inter-American Development Bank.

Czernich, Nina, Oliver Falck, Tobias Kretschmer, and Ludger Woessmann. 2011. "Broadband infrastructure and economic growth.” Economic Journal 121 (552): 505-532.

Dee, Thomas S. 2005. “A teacher like me: Does race, ethnicity, or gender matter?” American Economic Review 95 (2): 158-165.

Dee, Thomas S. 2007. "Teachers and the gender gaps in student achievement." Journal of Human Resources 42 (3): 528-554.

Economist, The (2013). E-ducation: A long-overdue technological revolution is at last under way. / Education technology: Catching on at last: New technology is poised to disrupt America's schools, and then the world's. The Economist, June 29: 13, 22-24.

Fairlie, Robert W., and Rebecca A. London. 2012. "The effects of home computers on educational outcomes: Evidence from a field experiment with community college students." Economic Journal 122 (561): 727-753.

Fairlie, Robert W., and Jonathan Robinson. 2013. "Experimental evidence on the effects of home computers on academic achievement among schoolchildren." American Economic Journal: Applied Economics 5 (3): 211-240.

Falck, Oliver, Robert Gold, and Stephan Heblich. 2014. "E-lections: Voting behavior and the Internet." American Economic Review 104 (7): 2238-2265.

Figlio, David, Mark Rush, and Lu Yin. 2013. "Is it live or is it Internet? Experimental estimates of the effects of online instruction on student learning." Journal of Labor Economics 31 (4): 763-784. 
Fuchs, Thomas, and Ludger Woessmann. 2004. "Computers and student learning: Bivariate and multivariate evidence on the availability and use of computers at home and at school." Brussels Economic Review 47 (3/4): 359-385.

Goolsbee, Austan, and Jonathan Guryan. 2006. "The impact of Internet subsidies in public schools." Review of Economics and Statistics 88 (2): 336-347.

Hanushek, Eric A. 2002. "Publicly provided education." In Handbook of Public Economics, Vol. 4, edited by Alan J. Auerbach and Martin Feldstein, pp. 2045-2141. Amsterdam: North Holland.

Konrad, Franz-Michael. 2007. Geschichte der Schule: Von der Antike bis zur Gegenwart. München: C.H. Beck.

Lavy, Victor. 2014. "Do differences in schools' instruction time explain international achievement gaps? Evidence from developed and developing countries." Economic Journal, forthcoming.

Leuven, Edwin, Mikael Lindahl, Hessel Oosterbeek, and Dinand Webbink. 2007. "The effect of extra funding for disadvantaged pupils on achievement." Review of Economics and Statistics 89 (4): 721-736.

Linden, Leigh L. 2008. "Complement or substitute? The effect of technology on student achievement in India." http://www.leighlinden.com/Gyan_Shala_CAL_2008-06-03.pdf (accessed 10/5/2014).

Machin, Stephen, Sandra McNally, and Olmo Silva. 2007. "New technology in schools: Is there a payoff?" Economic Journal 117 (522): 1145-1167.

Metzler, Johannes, and Ludger Woessmann. 2012. "The impact of teacher subject knowledge on student achievement: Evidence from within-teacher within-student variation." Journal of Development Economics 99 (2): 486-496.

Peterson, Paul E. 2010. Saving Schools: From Horace Mann to Virtual Learning. Cambridge, MA: Belknap Press of Harvard University Press.

Pritchett, Lant. 2013. The Rebirth of Education: Schooling Ain't Learning. Washington, DC: Center for Global Development.

Rouse, Cecilia E., and Alan B. Krueger. 2004. "Putting computerized instruction to the test: A randomized evaluation of a scientifically based reading program." Economics of Education Review 23 (4): 323-338.

Schwerdt, Guido, and Amelie C. Wuppermann. 2011. "Is traditional teaching really all that bad? A within-student between-subject approach." Economics of Education Review 30 (2): $365-379$. 
Table 1: Intensity of different types of computer use

\begin{tabular}{|c|c|c|c|c|c|c|c|}
\hline & \multicolumn{2}{|c|}{ Computer use intensity } & \multicolumn{5}{|c|}{ Separate categories of computer use } \\
\hline & $\begin{array}{c}\text { Mean } \\
(1) \\
\end{array}$ & $\begin{array}{c}\text { Std. dev. } \\
(2) \\
\end{array}$ & $\begin{array}{c}\text { No computer } \\
\text { available } \\
(3) \\
\end{array}$ & $\begin{array}{c}\text { Never or } \\
\text { almost never } \\
(4) \\
\end{array}$ & $\begin{array}{c}\text { Once or twice } \\
\text { a month } \\
(5)\end{array}$ & $\begin{array}{c}\text { Once or twice } \\
\text { a week } \\
(6) \\
\end{array}$ & $\begin{array}{c}\text { Every or almost } \\
\text { every day } \\
(7) \\
\end{array}$ \\
\hline \multicolumn{8}{|l|}{$8^{\text {th }}$ grade } \\
\hline \multicolumn{8}{|l|}{ Math } \\
\hline Look up ideas and information & 0.624 & 1.027 & 0.684 & 0.107 & 0.138 & 0.054 & 0.018 \\
\hline Practice skills and procedures & 0.636 & 1.048 & 0.684 & 0.104 & 0.131 & 0.061 & 0.021 \\
\hline Process and analyze data & 0.573 & 0.951 & 0.684 & 0.136 & 0.126 & 0.041 & 0.013 \\
\hline \multicolumn{8}{|l|}{ Science } \\
\hline Look up ideas and information & 0.938 & 1.254 & 0.604 & 0.056 & 0.179 & 0.122 & 0.039 \\
\hline Practice skills and procedures & 0.812 & 1.131 & 0.604 & 0.118 & 0.165 & 0.085 & 0.027 \\
\hline Process and analyze data & 0.781 & 1.084 & 0.604 & 0.127 & 0.176 & 0.072 & 0.021 \\
\hline \multicolumn{8}{|l|}{$4^{\text {th }}$ grade } \\
\hline \multicolumn{8}{|l|}{ Math } \\
\hline Look up ideas and information & 0.757 & 1.103 & 0.629 & 0.124 & 0.143 & 0.077 & 0.027 \\
\hline Practice skills and procedures & 0.909 & 1.269 & 0.629 & 0.060 & 0.144 & 0.123 & 0.043 \\
\hline \multicolumn{8}{|l|}{ Science } \\
\hline Look up ideas and information & 1.041 & 1.269 & 0.571 & 0.053 & 0.212 & 0.128 & 0.037 \\
\hline Practice skills and procedures & 0.886 & 1.140 & 0.571 & 0.139 & 0.175 & 0.090 & 0.025 \\
\hline
\end{tabular}

Samples of $8^{\text {th }}$-grade and $4^{\text {th }}$-grade students, respectively, in TIMSS 2011. (1)-(2): Mean and standard deviation of computer use for the respective activity in the respective subject (0 = no computer available, 1 = never or almost never, 2 = once or twice a month, 3 = once or twice a week, $4=$ every or almost every day). (3)-(7): Share of students in the respective category of computer use. Observations: 155,948 students in $8^{\text {th }}$ grade and 245,482 students in $4^{\text {th }}$ grade. 
Table 2: Cross-sectional regressions, $8^{\text {th }}$ grade

\begin{tabular}{|c|c|c|c|c|c|c|c|c|}
\hline & \multicolumn{6}{|c|}{ OLS } & \multicolumn{2}{|c|}{ SUR } \\
\hline & (1) & $(2)$ & (3) & (4) & (5) & (6) & (7) & (8) \\
\hline & Math & Science & Math & Science & Math & Science & Math & Science \\
\hline \multicolumn{9}{|l|}{ Specific computer uses } \\
\hline Look up ideas and information & $\begin{array}{c}-0.0367 \\
(0.0251)\end{array}$ & $\begin{array}{c}0.0094 \\
(0.0211)\end{array}$ & $\begin{array}{c}-0.0210 \\
(0.0235)\end{array}$ & $\begin{array}{c}-0.0068 \\
(0.0198)\end{array}$ & $\begin{array}{c}-0.0206 \\
(0.0222)\end{array}$ & $\begin{array}{c}-0.0099 \\
(0.0192)\end{array}$ & $\begin{array}{l}-0.0190 * \\
(0.0114)\end{array}$ & $\begin{array}{l}0.0225^{* *} \\
(0.0090)\end{array}$ \\
\hline Practice skills and procedures & $\begin{array}{c}-0.0504^{* *} \\
(0.0248)\end{array}$ & $\begin{array}{c}-0.0525^{* *} \\
(0.0217)\end{array}$ & $\begin{array}{c}-0.0689 * * * \\
(0.0232)\end{array}$ & $\begin{array}{c}-0.0232 \\
(0.0204)\end{array}$ & $\begin{array}{c}-0.0572 * * * \\
(0.0220)\end{array}$ & $\begin{array}{c}-0.0214 \\
(0.0202)\end{array}$ & $\begin{array}{c}-0.0139 \\
(0.0115)\end{array}$ & $\begin{array}{c}-0.0199 * * \\
(0.0100)\end{array}$ \\
\hline Process and analyze data & $\begin{array}{c}0.0906 * * * \\
(0.0251)\end{array}$ & $\begin{array}{c}0.0771^{* * * *} \\
(0.0206)\end{array}$ & $\begin{array}{c}0.0983 * * * \\
(0.0230)\end{array}$ & $\begin{array}{c}0.0683^{* * * *} \\
(0.0194)\end{array}$ & $\begin{array}{c}0.0994 * * * \\
(0.0216)\end{array}$ & $\begin{array}{c}0.0822 * * * \\
(0.0192)\end{array}$ & $\begin{array}{c}0.0360 * * * \\
(0.0112)\end{array}$ & $\begin{array}{c}0.0080 \\
(0.0089)\end{array}$ \\
\hline \multicolumn{9}{|l|}{ Combined computer use } \\
\hline Combined computer use & $\begin{array}{c}0.0037 \\
(0.0090)\end{array}$ & $\begin{array}{c}0.0328^{* * * *} \\
(0.0081)\end{array}$ & $\begin{array}{c}0.0084 \\
(0.0086)\end{array}$ & $\begin{array}{c}0.0371^{* * * *} \\
(0.0077)\end{array}$ & $\begin{array}{c}0.0213^{* * *} \\
(0.0081)\end{array}$ & $\begin{array}{c}0.0491^{* * * *} \\
(0.0075)\end{array}$ & $\begin{array}{c}0.0032 \\
(0.0039)\end{array}$ & $\begin{array}{c}0.0107 * * * \\
(0.0036)\end{array}$ \\
\hline Basic controls & yes & yes & yes & yes & yes & yes & yes & yes \\
\hline Teacher controls & no & no & yes & yes & yes & yes & yes & yes \\
\hline Teaching-method controls & no & no & no & no & yes & yes & yes & yes \\
\hline Observations & 155,948 & 155,948 & 155,948 & 155,948 & 155,948 & 155,948 & 155,948 & 155,948 \\
\hline Clusters & 6,091 & 6,091 & 6,091 & 6,091 & 6,091 & 6,091 & 6,091 & 6,091 \\
\hline
\end{tabular}

Dependent variable: TIMSS student test score in math and science, respectively. Top and bottom panel in each column report separate estimations. Columns (1)-(6): Separate OLS regressions. Columns (7)-(8): Seemingly unrelated regressions (SUR). Regressions weighted by students' sampling probability. See Table A3 in the appendix for lists of control variables. Robust standard errors adjusted for clustering at the classroom level in parentheses. Significance levels: * $10 \%, * * 5 \%, * * * 1 \%$. 
Table 3: Conventional fixed effects models

\begin{tabular}{|c|c|c|c|c|c|c|}
\hline & \multicolumn{3}{|c|}{$8^{\text {th }}$ grade } & \multicolumn{3}{|c|}{$4^{\text {th }}$ grade } \\
\hline & (1) & $(2)$ & (3) & (4) & (5) & (6) \\
\hline \multicolumn{7}{|l|}{ Specific computer uses } \\
\hline Look up ideas and information & $\begin{array}{c}0.0519 * * * \\
(0.0079)\end{array}$ & $\begin{array}{c}0.0467 * * * \\
(0.0079)\end{array}$ & $\begin{array}{c}0.0403 * * * \\
(0.0082)\end{array}$ & $\begin{array}{l}-0.0010 \\
(0.0037)\end{array}$ & $\begin{array}{c}0.0133 * * * \\
(0.0039)\end{array}$ & $\begin{array}{c}0.0150 * * * \\
(0.0039)\end{array}$ \\
\hline Practice skills and procedures & $\begin{array}{c}-0.0432 * * * \\
(0.0091)\end{array}$ & $\begin{array}{c}-0.0415 * * * \\
(0.0090)\end{array}$ & $\begin{array}{c}-0.0382 * * * \\
(0.0089)\end{array}$ & $\begin{array}{l}-0.0058 * \\
(0.0035)\end{array}$ & $\begin{array}{c}-0.0166 * * * \\
(0.0037)\end{array}$ & $\begin{array}{c}-0.0201 * * * \\
(0.0038)\end{array}$ \\
\hline Process and analyze data & $\begin{array}{l}-0.0001 \\
(0.0097) \\
\end{array}$ & $\begin{array}{c}0.0018 \\
(0.0095) \\
\end{array}$ & $\begin{array}{c}0.0029 \\
(0.0092) \\
\end{array}$ & & & \\
\hline \multicolumn{7}{|l|}{ Combined computer use } \\
\hline Combined computer use & $\begin{array}{c}0.0132 * * * \\
(0.0038)\end{array}$ & $\begin{array}{c}0.0109 * * * \\
(0.0038)\end{array}$ & $\begin{array}{c}0.0079 * * \\
(0.0039)\end{array}$ & $\begin{array}{c}-0.008 * * \\
(0.0037) \\
\end{array}$ & $\begin{array}{l}-0.0043 \\
(0.0036) \\
\end{array}$ & $\begin{array}{c}-0.0066^{*} \\
(0.0036) \\
\end{array}$ \\
\hline Student fixed effects & yes & yes & yes & yes & yes & yes \\
\hline Basic controls & yes & yes & yes & yes & yes & yes \\
\hline Teacher controls & no & yes & yes & no & yes & yes \\
\hline Teaching-method controls & no & no & yes & no & no & yes \\
\hline Observations & 311,722 & 311,722 & 311,722 & 490,964 & 490,964 & 490,964 \\
\hline Students & 155,861 & 155,861 & 155,861 & 245,482 & 245,482 & 245,482 \\
\hline Clusters & 6,091 & 6,091 & 6,091 & 11,992 & 11,992 & 11,992 \\
\hline
\end{tabular}

Dependent variable: TIMSS student test score in math and science. Top and bottom panel in each column report separate estimations. OLS regressions with student fixed effects, pooling both subjects. Regressions weighted by students' sampling probability. See Table A3 in the appendix for lists of control variables. Robust standard errors adjusted for clustering at the classroom level in parentheses. Significance levels: * $10 \%, * * 5 \%, * * * 1 \%$. 
Table 4: The effect of different types of computer use on student achievement: Within-student between-subject estimation, $8^{\text {th }}$ grade

\begin{tabular}{|c|c|c|c|c|c|c|}
\hline & \multicolumn{2}{|c|}{ (1) } & \multicolumn{2}{|c|}{$(2)$} & \multicolumn{2}{|c|}{ (3) } \\
\hline & Math & Science & Math & Science & Math & Science \\
\hline \multicolumn{7}{|l|}{ Specific computer uses } \\
\hline \multicolumn{7}{|c|}{ Look up ideas and information } \\
\hline Implied $\beta$ & $\begin{array}{c}-0.0137 \\
{[1.50]}\end{array}$ & $\begin{array}{c}0.0604 * * * \\
{[27.07]}\end{array}$ & $\begin{array}{l}-0.0095 \\
{[0.79]}\end{array}$ & $\begin{array}{c}0.0412 * * * \\
{[15.80]}\end{array}$ & $\begin{array}{c}-0.0130 \\
{[1.58]}\end{array}$ & $\begin{array}{c}0.0326 * * * \\
{[11.25]}\end{array}$ \\
\hline$\beta_{\text {math }}-\beta_{\text {science }}$ & \multicolumn{2}{|c|}{$-0.0741^{* * *}$} & \multicolumn{2}{|c|}{$-0.0507^{* * *}$} & \multicolumn{2}{|c|}{$-0.0457 * * *$} \\
\hline$\eta_{\text {math }}-\eta_{\text {science }}$ & \multicolumn{2}{|c|}{-0.0231} & \multicolumn{2}{|c|}{-0.0366} & \multicolumn{2}{|c|}{-0.0363} \\
\hline \multicolumn{7}{|l|}{ Practice skills and procedures } \\
\hline Implied $\beta$ & $\begin{array}{c}-0.0133 \\
{[1.46]}\end{array}$ & $\begin{array}{c}-0.0492 * * * \\
{[16.68]}\end{array}$ & $\begin{array}{l}-0.0057 \\
{[0.30]}\end{array}$ & $\begin{array}{c}-0.0311 * * * \\
{[7.33]}\end{array}$ & $\begin{array}{c}-0.0016 \\
{[0.03]}\end{array}$ & $\begin{array}{c}-0.0200^{*} \\
{[3.63]}\end{array}$ \\
\hline$\beta_{\text {math }}-\beta_{\text {science }}$ & \multicolumn{2}{|c|}{$0.0359 * *$} & \multicolumn{2}{|c|}{$0.0255^{*}$} & \multicolumn{2}{|c|}{0.0183} \\
\hline$\eta_{\text {math }}-\eta_{\text {science }}$ & \multicolumn{2}{|c|}{0.0332} & \multicolumn{2}{|c|}{$0.0572 * *$} & \multicolumn{2}{|c|}{$0.0482 *$} \\
\hline \multicolumn{7}{|l|}{ Process and analyze data } \\
\hline Implied $\beta$ & $\begin{array}{c}0.0207^{*} \\
{[3.48]}\end{array}$ & $\begin{array}{l}-0.0038 \\
{[0.14]}\end{array}$ & $\begin{array}{l}0.0069 \\
{[0.41]}\end{array}$ & $\begin{array}{l}-0.0062 \\
{[0.42]}\end{array}$ & $\begin{array}{l}0.0091 \\
{[0.83]}\end{array}$ & $\begin{array}{c}-0.0129 \\
{[1.97]}\end{array}$ \\
\hline$\beta_{\text {math }}-\beta_{\text {science }}$ & \multicolumn{2}{|c|}{$0.0246^{*}$} & \multicolumn{2}{|c|}{0.0132} & \multicolumn{2}{|c|}{$0.0220^{*}$} \\
\hline$\eta_{\text {math }}-\eta_{\text {science }}$ & \multicolumn{2}{|c|}{0.0124} & \multicolumn{2}{|c|}{0.0025} & \multicolumn{2}{|c|}{0.0183} \\
\hline \multicolumn{7}{|l|}{ Combined computer use } \\
\hline Implied $\beta$ & $\begin{array}{c}-0.0059 \\
{[2.24]}\end{array}$ & $\begin{array}{l}0.0073 \\
{[2.71]}\end{array}$ & $\begin{array}{c}-0.0080^{* *} \\
{[4.41]}\end{array}$ & $\begin{array}{l}0.0039 \\
{[0.88]}\end{array}$ & $\begin{array}{c}-0.0056 \\
{[2.29]}\end{array}$ & $\begin{array}{c}-0.0001 \\
{[0.00]}\end{array}$ \\
\hline$\beta_{\text {math }}-\beta_{\text {science }}$ & \multicolumn{2}{|c|}{$-0.0132^{* * *}$} & \multicolumn{2}{|c|}{$-0.0119 * *$} & \multicolumn{2}{|c|}{-0.0055} \\
\hline$\eta_{\text {math }}-\eta_{\text {science }}$ & \multicolumn{2}{|c|}{0.0220} & \multicolumn{2}{|c|}{0.0219} & & \\
\hline Basic controls & & & & & & \\
\hline Teacher controls & & & & & & \\
\hline Teaching-method controls & & & & & & \\
\hline Observations & & & & & & \\
\hline Clusters & & & & & & \\
\hline
\end{tabular}

Dependent variable: TIMSS student test score in math and science, respectively. Top and bottom panel in each column report separate estimations. Correlated random effects models estimated by seemingly unrelated regressions (SUR). Implied $\beta$ represents the effect of the respective computer use category implied in the correlated random effects model,

estimated according to equation (5). Regressions weighted by students' sampling probability. See Table A3 in the appendix for lists of control variables. $\chi^{2}$ statistics adjusted for clustering at the classroom level in brackets. Significance levels: * $10 \%, * * 5 \%, * * * 1 \%$. 
Table 5: The effect of different types of computer use on student achievement: Within-student between-subject estimation, $4^{\text {th }}$ grade

Full sample

(1)

Math

1)

Science

(2)

\section{Specific computer uses}

Look up ideas and information

\begin{tabular}{|c|c|c|c|c|}
\hline Implied $\beta$ & $\begin{array}{c}0.0194 * * * \\
{[10.40]}\end{array}$ & $\begin{array}{l}0.0079 \\
{[1.22]}\end{array}$ & $\begin{array}{c}0.0229 * * * \\
{[16.00]}\end{array}$ & $\begin{array}{l}0.0095 \\
{[1.90]}\end{array}$ \\
\hline$\beta_{\text {math }}-\beta_{\text {science }}$ & \multicolumn{2}{|c|}{0.0115} & \multicolumn{2}{|c|}{0.0134} \\
\hline$\eta_{\text {math }}-\eta_{\text {science }}$ & \multicolumn{2}{|c|}{0.0176} & \multicolumn{2}{|c|}{-0.0088} \\
\hline
\end{tabular}

Practice skills and procedures

Implied $\beta$

$\beta_{\text {math }}-\beta_{\text {science }}$

$-0.0115^{*} \quad-0.0232 * * *$

$-0.0191 * * * \quad-0.0282 * * *$

[3.49]

[11.26]

[10.46]

[18.19]

0.0091

0.0116

$0.0506 * * *$

$\begin{array}{cc}0.0386^{* * *} & 0.0008 \\ {[30.58]} & {[0.01]} \\ 0.0378^{* * *} \\ 0.0411^{* *}\end{array}$

$\begin{array}{cc}0.0369 * * * & 0.0032 \\ {[29.34]} & {[0.19]} \\ 0.0337 * * * \\ 0.0084\end{array}$

(3)

Same-teacher sample

$\eta_{\text {math }}-\eta_{\text {science }}$

\section{Combined computer use}

$$
\text { Implied } \beta
$$

$$
\beta_{\text {math }}-\beta_{\text {science }}
$$

$$
\text { [3.72] }
$$

$\eta_{\text {math }}-\eta_{\text {science }}$

Basic controls

Teacher controls

Teaching-method controls

0.0128

$$
\begin{array}{cc}
-0.0218 * * * & -0.0086 \\
{[9.76]} & {[1.43]} \\
-0.0133 \\
0.0588 * * *
\end{array}
$$

$0.0226 * * *$

0.0036

$-0.0189 * * *$
$0.0237 * * *$
0.0040
[29.06]
[0.83]
$0.0197 * * *$

$0.0225 * * *$

$0.0521 * * *$

$0.0423 * * *$

yes

yes

yes

yes

no

yes

no
$0.0145 * * * \quad-0.0063$
[11.27] [2.23] $0.0208 * * *$
$0.0677 * * *$ yes not applicable

\section{Observations}

245,482

159,621

8,123

Clusters 11,992

11,992

159,621
according to equation (5). Regressions weighted by students' sampling probability. See Table A5 in the appendix for lists of control variables. $\chi^{2}$ statistics adjusted for clustering at the classroom level in brackets. Significance levels: * $10 \%, * * 5 \%, * * * 1 \%$. 
Table 6: The effect of computer use by students' gender

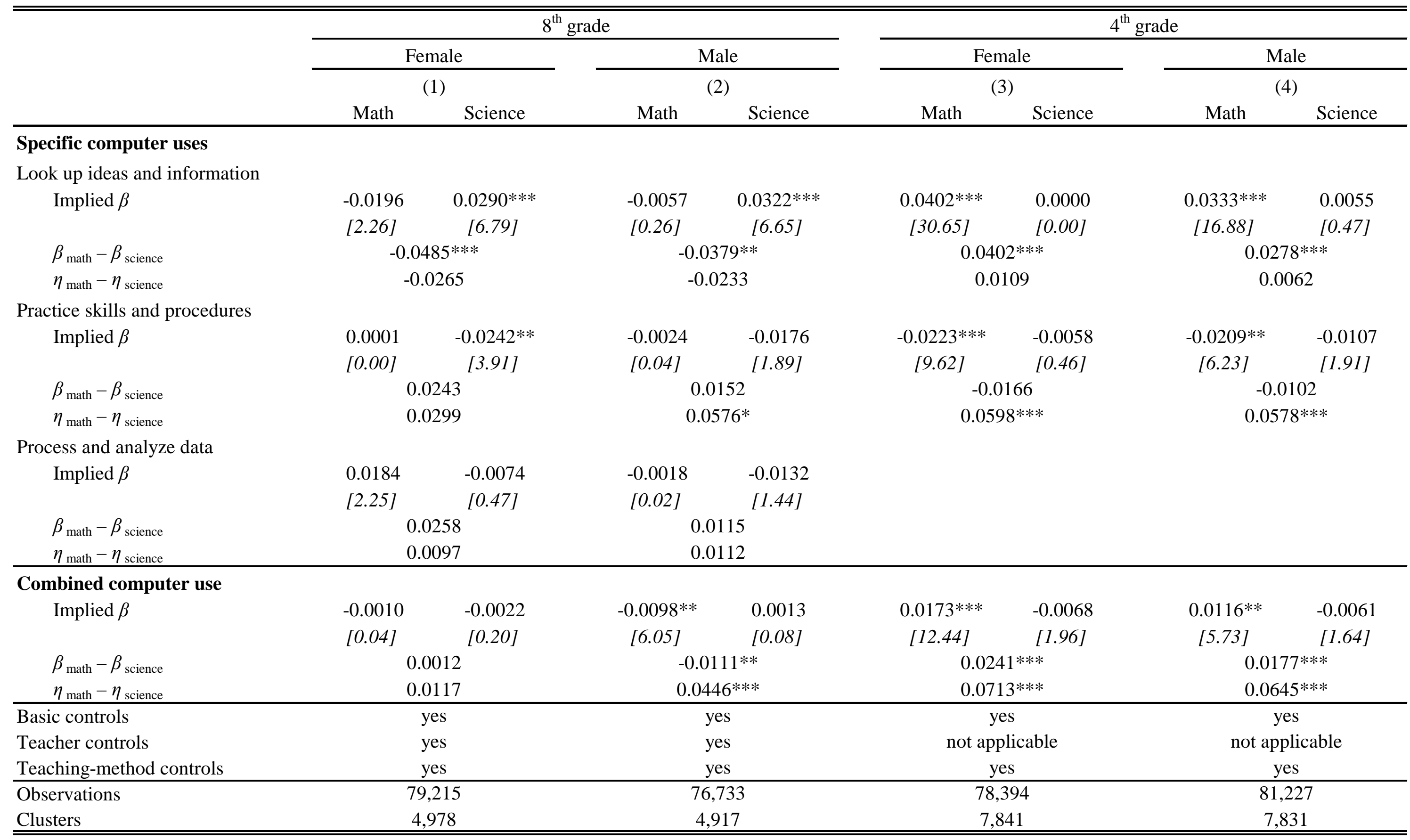

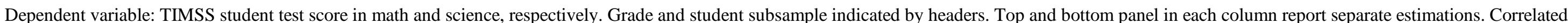
random effects models estimated by seemingly unrelated regressions (SUR). Implied $\beta$ represents the effect of the respective computer use category implied in the correlated random effects model, estimated

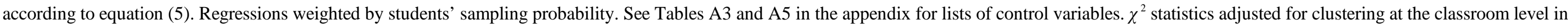
brackets. Significance levels: * 10\%, ** 5\%,*** $1 \%$. 
Table 7: The effect of computer use by students' achievement level

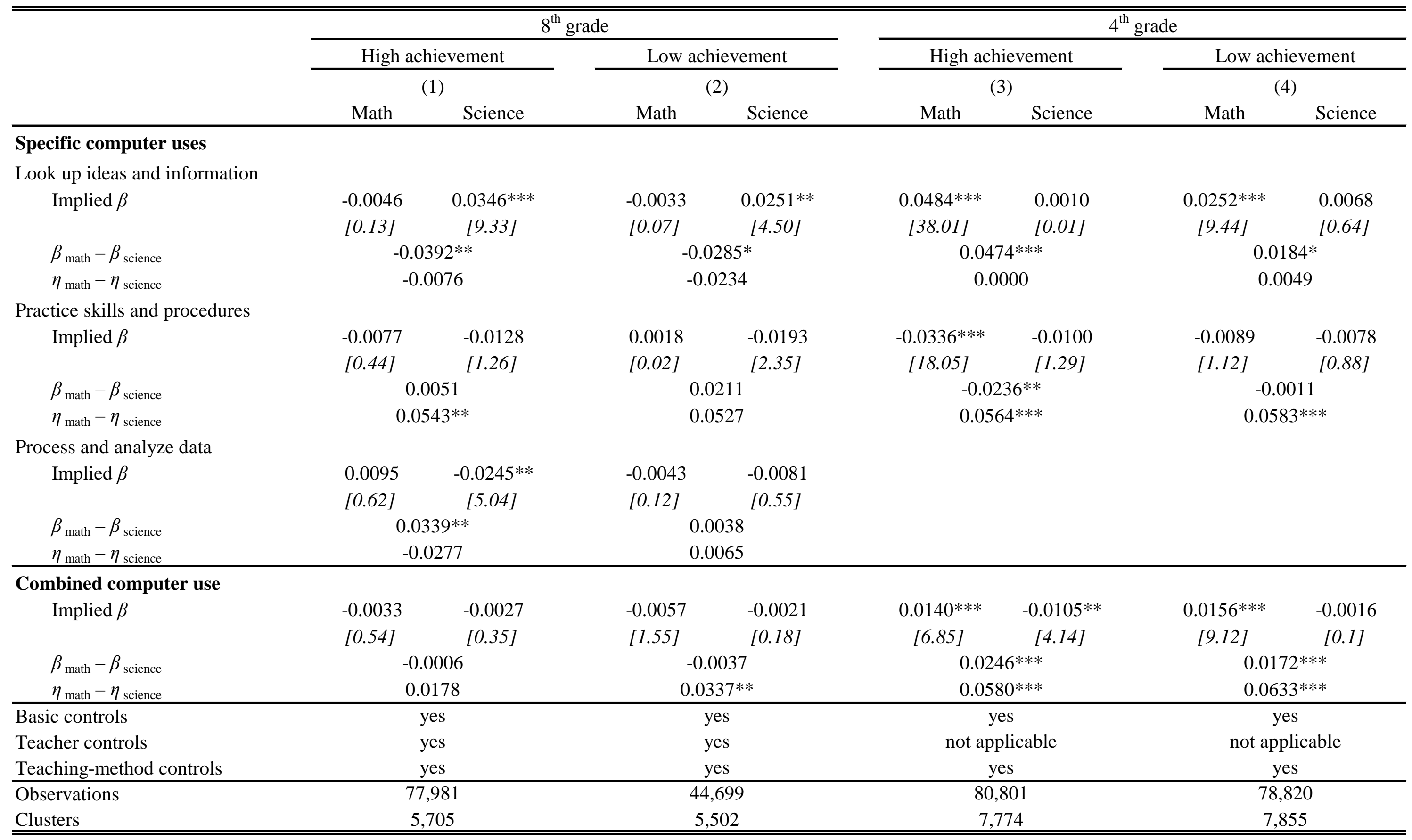

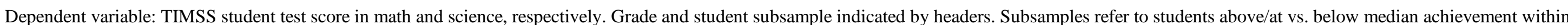
each country. Top and bottom panel in each column report separate estimations. Correlated random effects models estimated by seemingly unrelated regressions (SUR). Implied $\beta$ represents the effect of the respective computer use category implied in the correlated random effects model, estimated according to equation (5). Regressions weighted by students’ sampling probability. See Tables A3 and A5 in the appendix for lists of control variables. $\chi^{2}$ statistics adjusted for clustering at the classroom level in brackets. Significance levels: * $10 \%$, ** $5 \%$, *** $1 \%$. 
Table 8: The effect of computer use by students' socioeconomic background

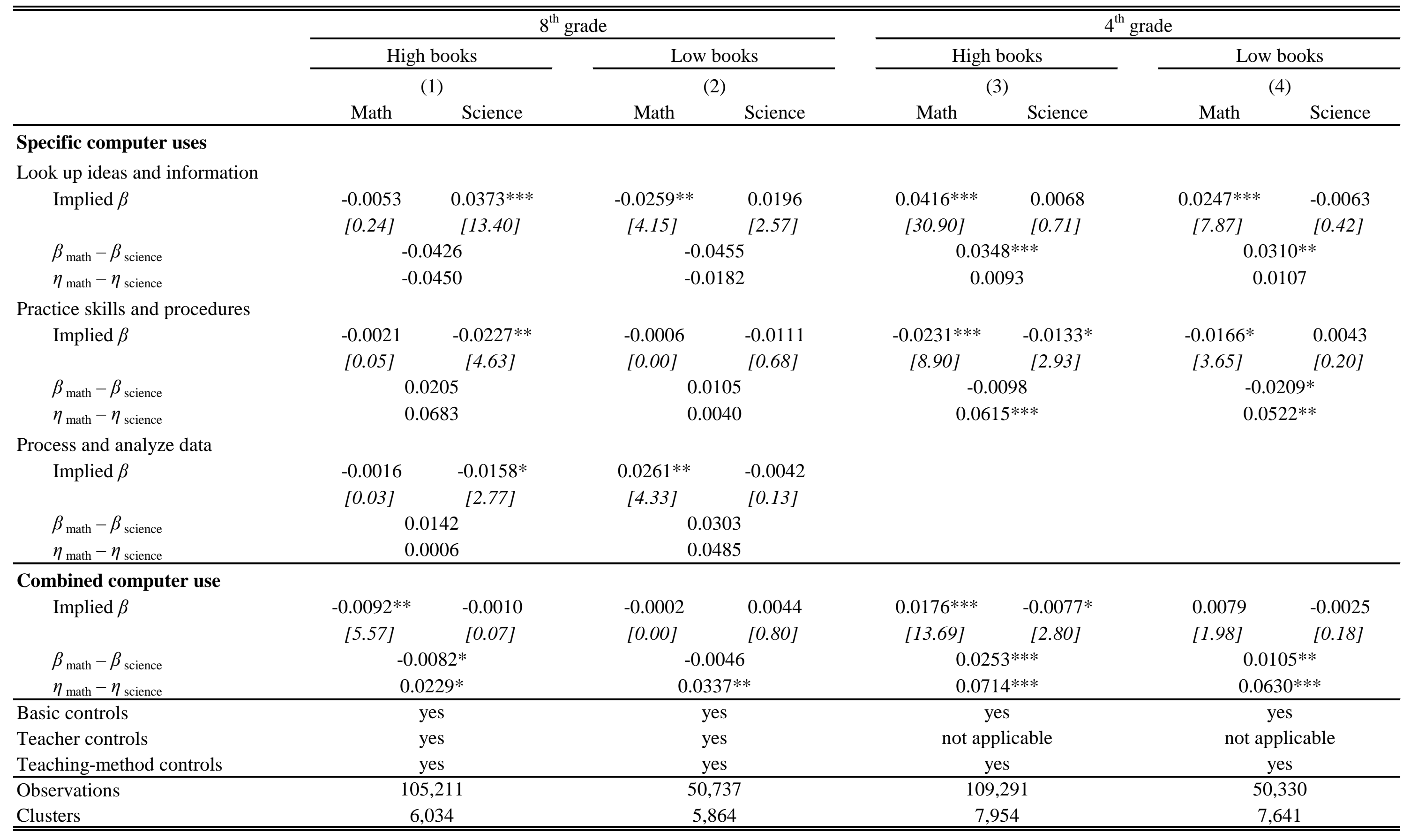

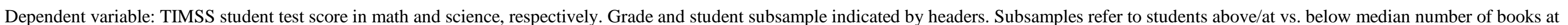

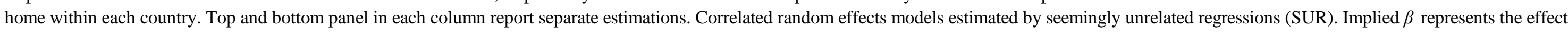

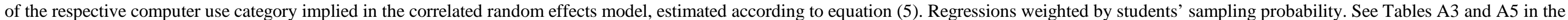
appendix for lists of control variables. $\chi^{2}$ statistics adjusted for clustering at the classroom level in brackets. Significance levels: * $10 \%$, ** $5 \%$, *** $1 \%$. 
Table 9: The effect of computer use in OECD and non-OECD countries

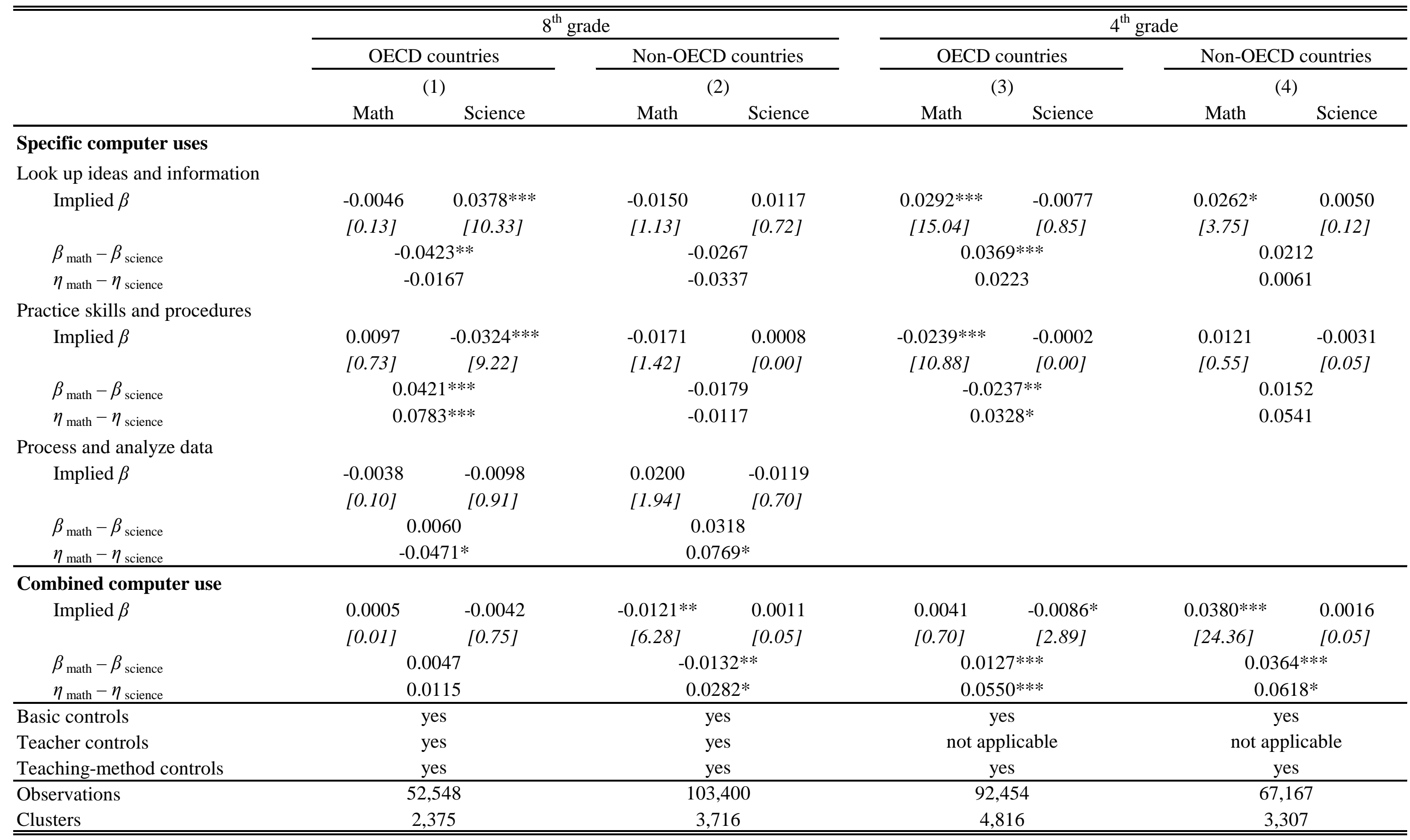

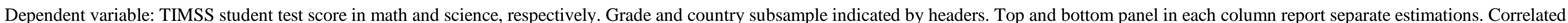
random effects models estimated by seemingly unrelated regressions (SUR). Implied $\beta$ represents the effect of the respective computer use category implied in the correlated random effects model, estimated

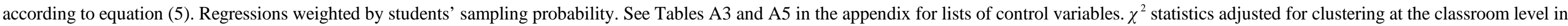
brackets. Significance levels: * 10\%, ** 5\%,*** $1 \%$. 
Table A1: Correlation of different types of computer use

\begin{tabular}{|c|c|c|c|c|c|c|}
\hline & \multicolumn{3}{|c|}{ Math } & \multicolumn{3}{|c|}{ Science } \\
\hline & $\begin{array}{c}\text { Look up ideas } \\
\text { and information } \\
\text { (1) }\end{array}$ & $\begin{array}{c}\text { Practice skills } \\
\text { and procedures } \\
(2) \\
\end{array}$ & $\begin{array}{l}\text { Process and } \\
\text { analyze data } \\
\text { (3) }\end{array}$ & $\begin{array}{c}\text { Look up ideas } \\
\text { and information } \\
(4)\end{array}$ & $\begin{array}{c}\text { Practice skills } \\
\text { and procedures } \\
(5) \\
\end{array}$ & $\begin{array}{c}\text { Process and } \\
\text { analyze data } \\
(6) \\
\end{array}$ \\
\hline \multicolumn{7}{|l|}{$8^{\text {th }}$ grade } \\
\hline \multicolumn{7}{|l|}{ Math } \\
\hline Look up ideas and information & 1.000 & & & & & \\
\hline Practice skills and procedures & 0.926 & 1.000 & & & & \\
\hline Process and analyze data & 0.935 & 0.925 & 1.000 & & & \\
\hline \multicolumn{7}{|l|}{ Science } \\
\hline Look up ideas and information & 0.289 & 0.291 & 0.275 & 1.000 & & \\
\hline Practice skills and procedures & 0.294 & 0.289 & 0.282 & 0.921 & 1.000 & \\
\hline Process and analyze data & 0.273 & 0.274 & 0.264 & 0.912 & 0.910 & 1.000 \\
\hline \multicolumn{7}{|l|}{$4^{\text {th }}$ grade } \\
\hline \multicolumn{7}{|l|}{ Math } \\
\hline Look up ideas and information & 1.000 & & & & & \\
\hline Practice skills and procedures & 0.896 & 1.000 & & & & \\
\hline \multicolumn{7}{|l|}{ Science } \\
\hline Look up ideas and information & 0.605 & 0.601 & & 1.000 & & \\
\hline Practice skills and procedures & 0.585 & 0.577 & & 0.911 & 1.000 & \\
\hline
\end{tabular}

Samples of $8^{\text {th }}$-grade and $4^{\text {th }}$-grade students, respectively, in TIMSS 2011. Correlation coefficients among the intensities of different types of computer use. All correlation coefficients are statistically significant at the $1 \%$ level. Observations: 155,948 students in $8^{\text {th }}$ grade and 245,482 students in $4^{\text {th }}$ grade. 
Table A2: Computer use and student achievement in $8^{\text {th }}$ grade across countries

\begin{tabular}{|c|c|c|c|c|c|c|c|c|}
\hline & $\begin{array}{c}\text { Computer } \\
\text { availability } \\
\text { (1) }\end{array}$ & $\begin{array}{l}\text { Look up ideas } \\
\text { and information } \\
(2)\end{array}$ & $\begin{array}{c}\text { Practice skills } \\
\text { and procedures } \\
\text { (3) } \\
\end{array}$ & $\begin{array}{l}\text { Process and } \\
\text { analyze data } \\
(4)\end{array}$ & $\begin{array}{c}\text { Between-subject } \\
\text { variation } \\
\text { (5) }\end{array}$ & $\begin{array}{c}\text { Math } \\
\text { score } \\
(6) \\
\end{array}$ & $\begin{array}{l}\text { Science } \\
\text { score } \\
(7) \\
\end{array}$ & $\begin{array}{c}\text { Number of } \\
\text { observations } \\
\text { (8) }\end{array}$ \\
\hline Australia & 0.687 & 1.442 & 1.463 & 1.311 & 0.649 & 513.6 & 527.4 & 3,660 \\
\hline Bahrain & 0.324 & 0.808 & 0.762 & 0.710 & 0.474 & 414.6 & 457.4 & 4,228 \\
\hline Botswana & 0.135 & 0.262 & 0.246 & 0.213 & 0.208 & 398.5 & 405.7 & 4,209 \\
\hline Canada (Alberta) & 0.666 & 1.410 & 1.272 & 1.238 & 0.601 & 504.7 & 544.6 & 3,743 \\
\hline Canada (Ontario) & 0.548 & 1.150 & 1.000 & 0.983 & 0.454 & 510.0 & 521.3 & 3,122 \\
\hline Canada (Quebec) & 0.355 & 0.675 & 0.604 & 0.552 & 0.559 & 535.1 & 523.4 & 4,115 \\
\hline Chile & 0.572 & 1.276 & 1.109 & 1.154 & 0.653 & 419.8 & 464.0 & 4,579 \\
\hline Chinese Taipei & 0.315 & 0.532 & 0.506 & 0.465 & 0.444 & 608.0 & 563.1 & 4,900 \\
\hline England & 0.568 & 1.105 & 1.011 & 0.951 & 0.602 & 497.2 & 522.2 & 2,039 \\
\hline Ghana & 0.141 & 0.249 & 0.247 & 0.241 & 0.202 & 335.0 & 309.6 & 6,031 \\
\hline Honduras, Republic of & 0.086 & 0.181 & 0.179 & 0.112 & 0.108 & 338.9 & 369.7 & 3,076 \\
\hline Hong Kong, SAR & 0.275 & 0.515 & 0.468 & 0.481 & 0.428 & 585.9 & 535.3 & 3,305 \\
\hline Indonesia & 0.299 & 0.564 & 0.507 & 0.510 & 0.282 & 384.2 & 402.5 & 2,231 \\
\hline Iran, Islamic Republic of & 0.252 & 0.463 & 0.425 & 0.435 & 0.260 & 412.7 & 472.3 & 5,739 \\
\hline Israel & 0.413 & 0.857 & 0.889 & 0.771 & 0.574 & 521.3 & 520.4 & 3,232 \\
\hline Italy & 0.336 & 0.680 & 0.599 & 0.577 & 0.254 & 496.7 & 498.2 & 3,295 \\
\hline Japan & 0.524 & 0.630 & 0.564 & 0.606 & 0.453 & 567.8 & 558.0 & 3,598 \\
\hline Jordan & 0.508 & 1.289 & 1.164 & 1.069 & 0.526 & 407.3 & 449.6 & 6,804 \\
\hline Korea, Republic of & 0.596 & 1.227 & 1.236 & 1.146 & 0.728 & 610.9 & 560.9 & 3,814 \\
\hline Malaysia & 0.109 & 0.279 & 0.267 & 0.253 & 0.197 & 442.0 & 426.5 & 5,002 \\
\hline New Zealand & 0.315 & 0.648 & 0.572 & 0.529 & 0.419 & 487.3 & 513.4 & 4,281 \\
\hline Oman & 0.206 & 0.545 & 0.468 & 0.443 & 0.311 & 368.7 & 422.9 & 7,451 \\
\hline Palestinian National Authority & 0.319 & 0.768 & 0.657 & 0.586 & 0.426 & 403.2 & 419.3 & 6,918 \\
\hline Qatar & 0.454 & 1.254 & 1.221 & 1.014 & 0.531 & 410.7 & 418.8 & 3,583 \\
\hline Saudi Arabia & 0.248 & 0.648 & 0.645 & 0.577 & 0.314 & 398.1 & 438.6 & 3,690 \\
\hline Singapore & 0.553 & 0.952 & 0.930 & 0.827 & 0.659 & 609.5 & 589.1 & 5,688 \\
\hline South Africa & 0.164 & 0.291 & 0.278 & 0.284 & 0.273 & 353.7 & 331.9 & 9,206 \\
\hline Sweden & 0.462 & 0.932 & 0.739 & 0.713 & 0.542 & 486.7 & 514.9 & 1,922 \\
\hline
\end{tabular}

(continued on next page) 
Table A2 (continued)

\begin{tabular}{|c|c|c|c|c|c|c|c|c|}
\hline & $\begin{array}{c}\text { Computer } \\
\text { availability } \\
\text { (1) } \\
\end{array}$ & $\begin{array}{c}\text { Look up ideas } \\
\text { and information } \\
(2)\end{array}$ & $\begin{array}{c}\text { Practice skills } \\
\text { and procedures } \\
\text { (3) }\end{array}$ & $\begin{array}{l}\text { Process and } \\
\text { analyze data } \\
\text { (4) }\end{array}$ & $\begin{array}{c}\text { Between-subject } \\
\text { variation } \\
\text { (5) }\end{array}$ & $\begin{array}{c}\text { Math } \\
\text { score } \\
(6)\end{array}$ & $\begin{array}{c}\text { Science } \\
\text { score } \\
(7)\end{array}$ & $\begin{array}{c}\text { Number of } \\
\text { observations } \\
\text { (8) }\end{array}$ \\
\hline Thailand & 0.252 & 0.627 & 0.565 & 0.532 & 0.393 & 427.1 & 450.3 & 5,908 \\
\hline Turkey & 0.361 & 0.927 & 0.844 & 0.820 & 0.491 & 455.2 & 484.3 & 6,474 \\
\hline United Arab Emirates & 0.372 & 0.999 & 0.944 & 0.847 & 0.527 & 445.8 & 452.8 & 9,110 \\
\hline United Arab Emirates (Abu Dhabi) & 0.309 & 0.803 & 0.780 & 0.674 & 0.482 & 441.8 & 454.3 & 3,010 \\
\hline United Arab Emirates (Dubai) & 0.401 & 1.095 & 0.975 & 0.871 & 0.481 & 463.9 & 469.9 & 3,311 \\
\hline United States & 0.519 & 0.998 & 0.997 & 0.967 & 0.667 & 514.0 & 531.3 & 4,674 \\
\hline Total & 0.365 & 0.781 & 0.724 & 0.677 & 0.440 & 463.7 & 473.6 & 155,948 \\
\hline
\end{tabular}

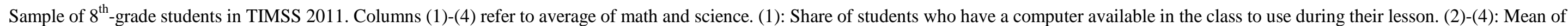

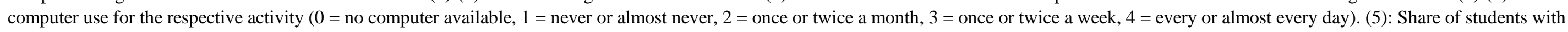
difference in computer use between math and science (average of the three use categories). (6)-(7): Mean of TIMSS score in the subject. (8): Number of student observations. 
Table A3: Descriptive statistics of control variables, $8^{\text {th }}$ grade

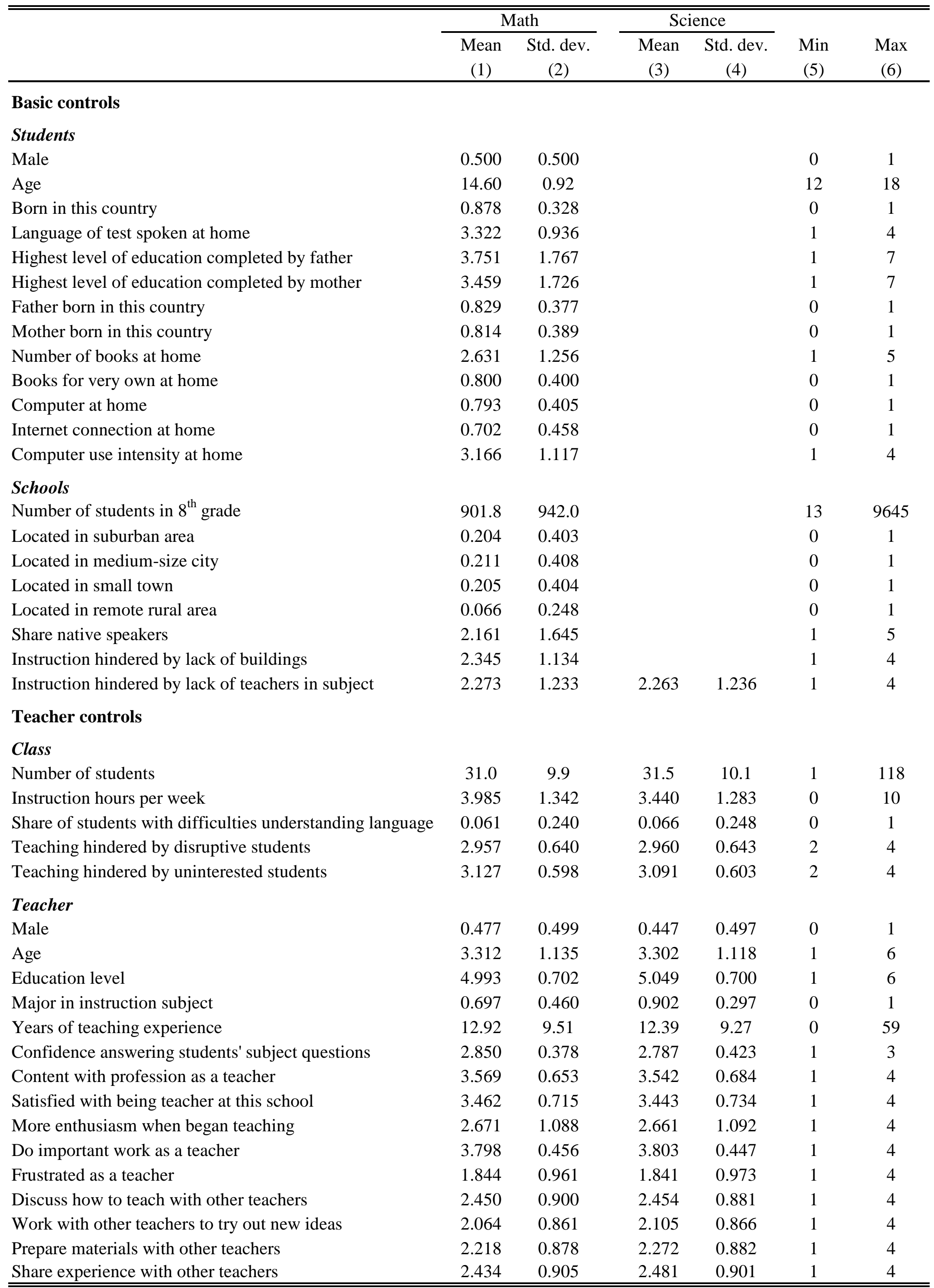

(continued on next page) 


\begin{tabular}{|c|c|c|c|c|c|c|}
\hline & \multicolumn{2}{|c|}{ Math } & \multicolumn{2}{|c|}{ Science } & \multirow[b]{2}{*}{$\begin{array}{c}\text { Min } \\
(5)\end{array}$} & \multirow[b]{2}{*}{$\begin{array}{r}\text { Max } \\
(6) \\
\end{array}$} \\
\hline & $\begin{array}{c}\text { Mean } \\
(1)\end{array}$ & $\begin{array}{c}\text { Std. dev. } \\
(2)\end{array}$ & $\begin{array}{c}\text { Mean } \\
(3) \\
\end{array}$ & $\begin{array}{c}\text { Std. dev. } \\
(4)\end{array}$ & & \\
\hline Visit another classroom to learn & 1.586 & 0.714 & 1.615 & 0.729 & 1 & 4 \\
\hline Participation in prof. dev. in subject assessment & 0.472 & 0.499 & 0.450 & 0.498 & 0 & 1 \\
\hline Participation in prof. dev. in subject content & 0.551 & 0.497 & 0.550 & 0.498 & 0 & 1 \\
\hline Participation in prof. dev. in subject curriculum & 0.522 & 0.500 & 0.512 & 0.500 & 0 & 1 \\
\hline Participation in prof. dev. in IT integration into subject & 0.438 & 0.496 & 0.446 & 0.497 & 0 & 1 \\
\hline Participation in prof. dev. in subject pedagogy & 0.576 & 0.494 & 0.555 & 0.497 & 0 & 1 \\
\hline Participation in prof. dev. in teaching critical thinking & 0.449 & 0.497 & 0.455 & 0.498 & 0 & 1 \\
\hline \multicolumn{7}{|l|}{ Teaching-method controls } \\
\hline Frequency correct homework assignments & 2.659 & 0.536 & 2.662 & 0.516 & 1 & 3 \\
\hline Frequency discuss homework in class & 2.600 & 0.556 & 2.613 & 0.551 & 1 & 3 \\
\hline Frequency let students listen & 2.642 & 0.666 & 1.733 & 0.830 & 0 & 3 \\
\hline Frequency let students memorize & 2.088 & 0.899 & 1.959 & 0.928 & 0 & 3 \\
\hline Frequency meet individual parents to discuss progress & 1.579 & 1.048 & 1.597 & 1.065 & 0 & 4 \\
\hline Frequency praise students for good effort & 2.711 & 0.581 & 2.661 & 0.619 & 0 & 3 \\
\hline Frequency use questioning to elicit explanations & 2.605 & 0.653 & 2.696 & 0.576 & 0 & 3 \\
\hline Frequency take tests & 1.680 & 0.828 & 1.720 & 0.826 & 0 & 3 \\
\hline Use of textbooks as supplement & 0.248 & 0.432 & 0.283 & 0.450 & 0 & 1 \\
\hline Use of textbooks as basis for instruction & 0.732 & 0.443 & 0.695 & 0.460 & 0 & 1 \\
\hline Use of workbooks as supplement & 0.616 & 0.486 & 0.599 & 0.490 & 0 & 1 \\
\hline Use of workbooks as basis for instruction & 0.351 & 0.477 & 0.358 & 0.479 & 0 & 1 \\
\hline Frequency encourage students to improve performance & 2.717 & 0.575 & 2.638 & 0.632 & 0 & 3 \\
\hline Frequency use homework to contribute towards grade & 2.228 & 0.752 & 2.309 & 0.722 & 1 & 3 \\
\hline Frequency monitor homework completed & 2.769 & 0.449 & 2.779 & 0.439 & 1 & 3 \\
\hline Emphasis on ongoing work for progress monitoring & 2.703 & 0.495 & 2.674 & 0.500 & 1 & 3 \\
\hline Emphasis on tests for progress monitoring & 2.762 & 0.442 & 2.721 & 0.473 & 1 & 3 \\
\hline Emphasis on central tests for progress monitoring & 2.070 & 0.760 & 2.039 & 0.775 & 1 & 3 \\
\hline Frequency relate lesson to students' daily lives & 2.017 & 0.847 & 2.475 & 0.721 & 0 & 3 \\
\hline Frequency send home progress report & 1.541 & 1.027 & 1.514 & 1.018 & 0 & 4 \\
\hline Frequency let students solve routine problems & 2.289 & 0.789 & 1.893 & 0.856 & 0 & 3 \\
\hline Frequency summarize what students should have learned & 2.596 & 0.692 & 2.605 & 0.687 & 0 & 3 \\
\hline Frequency give test or examination to class & 3.521 & 0.881 & 3.371 & 0.918 & 1 & 5 \\
\hline
\end{tabular}

Sample of $8^{\text {th }}$-grade students in TIMSS 2011. Mean, standard deviation, minimum, and maximum of the basic, teacher, and teaching-method control variables included in the regressions. 
Table A4: Measuring computer use by indicator variables, $8^{\text {th }}$ grade

\begin{tabular}{|c|c|c|c|c|}
\hline & \multicolumn{2}{|c|}{ At least once per week } & \multicolumn{2}{|c|}{ At least once per month } \\
\hline & \multicolumn{2}{|c|}{ (1) } & \multicolumn{2}{|c|}{$(2)$} \\
\hline & Math & Science & Math & Science \\
\hline \multicolumn{5}{|c|}{ Look up ideas and information } \\
\hline Implied $\beta$ & $\begin{array}{c}-0.0106 \\
{[0.39]}\end{array}$ & $\begin{array}{c}0.0242 * \\
{[3.49]}\end{array}$ & $\begin{array}{c}-0.0018 \\
{[0.01]}\end{array}$ & $\begin{array}{c}0.0347^{* * * *} \\
{[7.22]}\end{array}$ \\
\hline $\begin{array}{l}\beta_{\text {math }}-\beta_{\text {science }} \\
\eta_{\text {math }}-\eta_{\text {science }}\end{array}$ & $-0.0348 *$ & & $-0.0364 *$ & \\
\hline \multicolumn{5}{|l|}{ Practice skills and procedures } \\
\hline Implied $\beta$ & $\begin{array}{l}-0.0011 \\
{[0.00]}\end{array}$ & $\begin{array}{c}-0.0295^{*} \\
{[2.86]}\end{array}$ & $\begin{array}{c}-0.0333^{* *} \\
{[5.51]}\end{array}$ & $\begin{array}{l}-0.0136 \\
{[1.02]}\end{array}$ \\
\hline $\begin{array}{l}\beta_{\text {math }}-\beta \beta_{\text {science }} \\
\eta_{\text {math }}-\eta_{\text {science }}\end{array}$ & \multicolumn{2}{|c|}{0.0555} & \multicolumn{2}{|c|}{0.0440} \\
\hline \multicolumn{5}{|l|}{ Process and analyze data } \\
\hline Implied $\beta$ & $\begin{array}{c}-0.0069 \\
{[0.12]}\end{array}$ & $\begin{array}{l}-0.0047 \\
{[0.08]}\end{array}$ & $\begin{array}{l}0.0114 \\
{[0.56]}\end{array}$ & $\begin{array}{l}-0.0160 \\
{[1.46]}\end{array}$ \\
\hline$\beta_{\text {math }}-\beta_{\text {science }}$ & \multicolumn{2}{|c|}{-0.0022} & \multicolumn{2}{|c|}{0.0274} \\
\hline$\eta_{\text {math }}-\eta_{\text {science }}$ & \multicolumn{2}{|c|}{0.0773} & \multicolumn{2}{|c|}{-0.0112} \\
\hline Basic controls & \multicolumn{2}{|c|}{ yes } & \multicolumn{2}{|c|}{ yes } \\
\hline Teacher controls & \multicolumn{2}{|c|}{ yes } & \multicolumn{2}{|c|}{ yes } \\
\hline Teaching-method controls & \multicolumn{2}{|c|}{ yes } & \multicolumn{2}{|c|}{ yes } \\
\hline Observations & \multicolumn{2}{|c|}{155,948} & \multicolumn{2}{|c|}{155,948} \\
\hline Clusters & \multicolumn{2}{|c|}{6,091} & \multicolumn{2}{|c|}{6,091} \\
\hline
\end{tabular}

Dependent variable: TIMSS student test score in math and science, respectively. Correlated random effects models estimated by seemingly unrelated regressions (SUR). Implied $\beta$ represents the effect of the respective computer use category implied in the correltaed random effects model, estimated according to equation (5). Regressions weighted by students' sampling probability. See Table A3 in the appendix for lists of control variables. $\chi^{2}$ statistics adjusted for clustering at the classroom level in brackets. Significance levels: * $10 \%$, ** $5 \%, * * * 1 \%$. 
Table A5: Computer use and student achievement in $4^{\text {th }}$ grade across countries

\begin{tabular}{|c|c|c|c|c|c|c|c|c|}
\hline & $\begin{array}{c}\text { Computer } \\
\text { availability } \\
\text { (1) }\end{array}$ & $\begin{array}{c}\text { Look up ideas } \\
\text { and information } \\
(2)\end{array}$ & $\begin{array}{c}\text { Practice skills } \\
\text { and procedures } \\
\text { (3) }\end{array}$ & $\begin{array}{c}\text { Between-subject } \\
\text { variation } \\
\text { (4) }\end{array}$ & $\begin{array}{l}\text { Math } \\
\text { score } \\
(5)\end{array}$ & $\begin{array}{c}\text { Science } \\
\text { score } \\
(6)\end{array}$ & $\begin{array}{c}\text { Observations } \\
\text { (full sample) } \\
(7)\end{array}$ & $\begin{array}{c}\text { Obs. (same- } \\
\text { teacher sample) } \\
\text { (8) }\end{array}$ \\
\hline Armenia & 0.190 & 0.423 & 0.404 & 0.177 & 450.3 & 416.7 & 3,631 & 3,631 \\
\hline Australia & 0.775 & 1.811 & 1.696 & 0.601 & 519.3 & 521.4 & 3,732 & 3,377 \\
\hline Austria & 0.658 & 1.249 & 1.200 & 0.504 & 507.7 & 531.9 & 4,384 & 4,140 \\
\hline Azerbaijan, Republic of & 0.354 & 0.885 & 0.830 & 0.317 & 464.4 & 441.9 & 4,388 & 2,789 \\
\hline Bahrain & 0.317 & 0.801 & 0.767 & 0.408 & 436.4 & 450.0 & 3,846 & 88 \\
\hline Belgium (Flemish) & 0.681 & 1.396 & 1.401 & 0.638 & 549.5 & 509.4 & 4,495 & 4,495 \\
\hline Botswana & 0.053 & 0.112 & 0.112 & 0.056 & 447.3 & 406.8 & 1,993 & 1,196 \\
\hline Canada (Alberta) & 0.683 & 1.409 & 1.417 & 0.516 & 507.3 & 544.1 & 2,636 & 2,466 \\
\hline Canada (Ontario) & 0.460 & 0.938 & 0.855 & 0.389 & 516.8 & 528.4 & 3,720 & 3,485 \\
\hline Canada (Quebec) & 0.403 & 0.806 & 0.735 & 0.432 & 533.7 & 517.2 & 3,521 & 2,588 \\
\hline Chile & 0.611 & 1.407 & 1.370 & 0.399 & 460.9 & 479.4 & 3,665 & 3,665 \\
\hline Chinese Taipei & 0.519 & 1.125 & 1.172 & 0.653 & 592.0 & 553.3 & 4,270 & 161 \\
\hline Croatia & 0.121 & 0.248 & 0.228 & 0.096 & 489.9 & 517.5 & 4,509 & 4,509 \\
\hline Czech Republic & 0.513 & 0.990 & 1.110 & 0.426 & 510.6 & 536.9 & 4,296 & 3,400 \\
\hline Denmark & 0.752 & 1.434 & 1.434 & 0.578 & 539.2 & 529.7 & 2,603 & 1,366 \\
\hline England & 0.752 & 1.467 & 1.489 & 0.576 & 539.1 & 525.9 & 2,384 & 1,991 \\
\hline Finland & 0.626 & 1.116 & 1.184 & 0.433 & 548.3 & 572.5 & 4,017 & 3,825 \\
\hline Georgia & 0.195 & 0.493 & 0.456 & 0.216 & 448.4 & 456.2 & 4,284 & 3,005 \\
\hline Germany & 0.606 & 1.143 & 1.100 & 0.511 & 532.4 & 534.4 & 3,159 & 1,697 \\
\hline Honduras, Republic of & 0.048 & 0.127 & 0.131 & 0.064 & 412.4 & 450.5 & 2,212 & 2,212 \\
\hline Hong Kong, SAR & 0.496 & 1.034 & 1.052 & 0.660 & 600.9 & 535.8 & 3,186 & 437 \\
\hline Hungary & 0.352 & 0.706 & 0.722 & 0.284 & 514.4 & 535.5 & 4,740 & 3,660 \\
\hline Iran, Islamic Republic of & 0.058 & 0.122 & 0.129 & 0.044 & 429.7 & 453.7 & 5,582 & 5,582 \\
\hline Ireland & 0.586 & 1.172 & 1.123 & 0.432 & 527.3 & 518.1 & 4,271 & 4,271 \\
\hline Italy & 0.276 & 0.614 & 0.624 & 0.238 & 508.4 & 525.9 & 3,560 & 2,526 \\
\hline Japan & 0.656 & 0.914 & 0.816 & 0.433 & 584.9 & 560.3 & 3,614 & 2,253 \\
\hline Kazakhstan & 0.674 & 1.756 & 1.774 & 0.325 & 499.7 & 492.8 & 4,158 & 4,158 \\
\hline Korea, Republic of & 0.329 & 0.683 & 0.669 & 0.241 & 604.6 & 586.7 & 3,855 & 3,537 \\
\hline Kuwait & 0.255 & 0.608 & 0.610 & 0.374 & 340.6 & 350.0 & 3,696 & 26 \\
\hline Lithuania & 0.452 & 1.070 & 1.008 & 0.266 & 533.0 & 515.4 & 4,447 & 4,338 \\
\hline Malta & 0.394 & 0.743 & 0.734 & 0.368 & 515.0 & 480.2 & 1,315 & 813 \\
\hline
\end{tabular}

(continued on next page) 
Table A5 (continued)

\begin{tabular}{|c|c|c|c|c|c|c|c|c|}
\hline & $\begin{array}{c}\text { Computer } \\
\text { availability } \\
\text { (1) } \\
\end{array}$ & $\begin{array}{c}\text { Look up ideas } \\
\text { and information } \\
(2)\end{array}$ & $\begin{array}{c}\text { Practice skills } \\
\text { and procedures } \\
\text { (3) } \\
\end{array}$ & $\begin{array}{c}\text { Between-subject } \\
\text { variation } \\
(4) \\
\end{array}$ & $\begin{array}{l}\text { Math } \\
\text { score } \\
(5) \\
\end{array}$ & $\begin{array}{c}\text { Science } \\
\text { score } \\
(6) \\
\end{array}$ & $\begin{array}{c}\text { Observations } \\
\text { (full sample) } \\
(7) \\
\end{array}$ & $\begin{array}{c}\text { Observations } \\
\text { (same-teacher) } \\
(8) \\
\end{array}$ \\
\hline Morocco & 0.065 & 0.127 & 0.130 & 0.113 & 335.3 & 266.2 & 4,787 & 831 \\
\hline Netherlands & 0.735 & 1.549 & 1.791 & 0.709 & 538.6 & 531.6 & 1,955 & 1,955 \\
\hline New Zealand & 0.855 & 2.052 & 1.983 & 0.697 & 486.2 & 498.3 & 4,854 & 4,484 \\
\hline Northern Ireland & 0.767 & 1.754 & 1.702 & 0.520 & 563.8 & 517.8 & 2,878 & 2,780 \\
\hline Norway & 0.748 & 1.337 & 1.529 & 0.637 & 495.7 & 495.1 & 2,852 & 1,724 \\
\hline Oman & 0.155 & 0.346 & 0.323 & 0.142 & 387.3 & 381.5 & 9,421 & 3,947 \\
\hline Poland & 0.176 & 0.371 & 0.350 & 0.116 & 481.1 & 506.2 & 4,865 & 4,865 \\
\hline Portugal & 0.427 & 1.109 & 1.019 & 0.255 & 532.4 & 523.0 & 3,815 & 3,815 \\
\hline Qatar & 0.459 & 1.207 & 1.199 & 0.532 & 412.0 & 393.8 & 3,755 & 352 \\
\hline Romania & 0.248 & 0.558 & 0.583 & 0.127 & 481.3 & 505.3 & 4,342 & 4,342 \\
\hline Russian Federation & 0.318 & 0.717 & 0.752 & 0.152 & 540.9 & 551.8 & 4,393 & 4,290 \\
\hline Saudi Arabia & 0.221 & 0.558 & 0.521 & 0.332 & 409.2 & 429.8 & 4,081 & 29 \\
\hline Serbia & 0.111 & 0.227 & 0.212 & 0.088 & 517.7 & 518.4 & 4,232 & 4,232 \\
\hline Singapore & 0.639 & 1.371 & 1.431 & 0.556 & 606.2 & 584.3 & 5,815 & 3,173 \\
\hline Slovak Republic & 0.408 & 0.917 & 0.913 & 0.324 & 506.2 & 532.3 & 5,249 & 3,472 \\
\hline Slovenia & 0.353 & 0.719 & 0.642 & 0.274 & 513.2 & 520.6 & 4,225 & 4,201 \\
\hline Spain & 0.361 & 0.744 & 0.823 & 0.247 & 482.4 & 507.9 & 3,385 & 3,385 \\
\hline Sweden & 0.633 & 1.065 & 1.184 & 0.580 & 505.9 & 537.2 & 2,947 & 2,269 \\
\hline Thailand & 0.198 & 0.478 & 0.488 & 0.265 & 457.8 & 473.5 & 4,360 & 4,360 \\
\hline Tunisia & 0.115 & 0.235 & 0.239 & 0.157 & 359.1 & 346.4 & 4,687 & 3,303 \\
\hline Turkey & 0.360 & 1.008 & 1.044 & 0.207 & 470.1 & 464.8 & 7,252 & 7,252 \\
\hline United Arab Emirates & 0.330 & 0.892 & 0.843 & 0.407 & 437.2 & 433.3 & 11,035 & 2,250 \\
\hline United Arab Emirates (Abu Dhabi) & 0.310 & 0.880 & 0.811 & 0.369 & 422.2 & 418.1 & 3,370 & 242 \\
\hline United Arab Emirates (Dubai) & 0.421 & 1.188 & 1.172 & 0.436 & 475.7 & 472.6 & 4,040 & 1,742 \\
\hline United States & 0.640 & 1.282 & 1.431 & 0.508 & 540.9 & 545.2 & 9,448 & 8,145 \\
\hline Yemen & 0.162 & 0.319 & 0.317 & 0.205 & 248.0 & 214.8 & 6,559 & 934 \\
\hline Yemen (Grade 6) & 0.124 & 0.251 & 0.228 & 0.211 & 363.0 & 364.6 & 2,711 & 195 \\
\hline Total & 0.417 & 0.899 & 0.898 & 0.358 & 489.3 & 487.8 & 245,482 & 168,256 \\
\hline
\end{tabular}

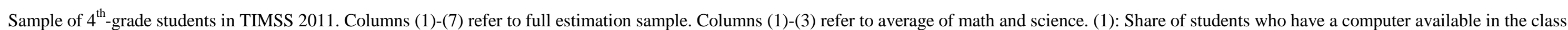

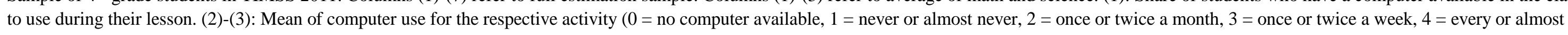

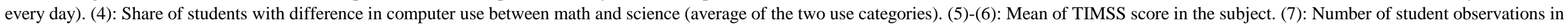
full estimation sample. (8): Number of student observations in same-teacher sample. 
Table A6: Descriptive statistics of control variables, $4^{\text {th }}$ grade

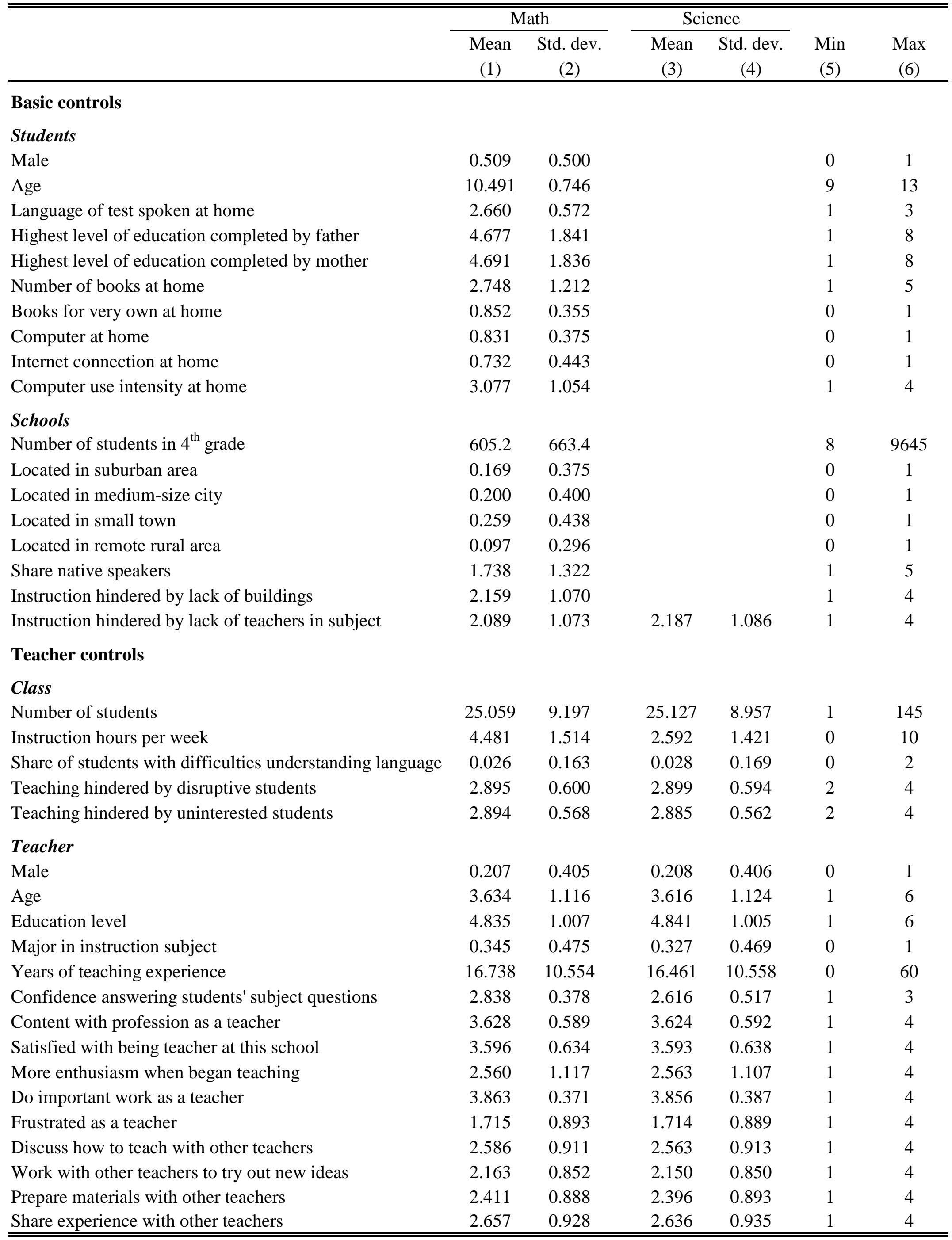

(continued on next page) 


\begin{tabular}{|c|c|c|c|c|c|c|}
\hline & \multicolumn{2}{|c|}{ Math } & \multicolumn{2}{|c|}{ Science } & \multirow[b]{2}{*}{$\begin{array}{l}\text { Min } \\
(5) \\
\end{array}$} & \multirow[b]{2}{*}{$\begin{array}{c}\text { Max } \\
(6) \\
\end{array}$} \\
\hline & $\begin{array}{c}\text { Mean } \\
(1) \\
\end{array}$ & $\begin{array}{c}\text { Std. dev. } \\
(2)\end{array}$ & $\begin{array}{c}\text { Mean } \\
(3) \\
\end{array}$ & $\begin{array}{c}\text { Std. dev. } \\
(4)\end{array}$ & & \\
\hline Visit another classroom to learn & 1.609 & 0.739 & 1.608 & 0.747 & 1 & 4 \\
\hline Participation in prof. dev. in subject assessment & 0.386 & 0.487 & 0.275 & 0.447 & 0 & 1 \\
\hline Participation in prof. dev. in subject content & 0.446 & 0.497 & 0.350 & 0.477 & 0 & 1 \\
\hline Participation in prof. dev. in subject curriculum & 0.417 & 0.493 & 0.336 & 0.472 & 0 & 1 \\
\hline Participation in prof. dev. in IT integration into subject & 0.328 & 0.470 & 0.284 & 0.451 & 0 & 1 \\
\hline Participation in prof. dev. in subject pedagogy & 0.471 & 0.499 & 0.339 & 0.473 & 0 & 1 \\
\hline \multicolumn{7}{|l|}{ Teaching-method controls } \\
\hline Frequency correct homework assignments & 2.766 & 0.463 & 2.723 & 0.501 & 1 & 3 \\
\hline Frequency discuss homework in class & 2.629 & 0.522 & 2.689 & 0.500 & 1 & 3 \\
\hline Frequency let students listen & 2.562 & 0.725 & 1.546 & 0.830 & 0 & 3 \\
\hline Frequency let students memorize & 1.949 & 0.919 & 1.730 & 1.012 & 0 & 3 \\
\hline Frequency meet individual parents to discuss progress & 2.120 & 1.041 & 2.066 & 1.072 & 0 & 4 \\
\hline Frequency praise students for good effort & 2.833 & 0.460 & 2.825 & 0.468 & 0 & 3 \\
\hline Frequency use questioning to elicit explanations & 2.725 & 0.568 & 2.752 & 0.537 & 0 & 3 \\
\hline Frequency take tests & 1.587 & 0.798 & 1.473 & 0.835 & 0 & 3 \\
\hline Use of textbooks as supplement & 0.219 & 0.413 & 0.225 & 0.417 & 0 & 1 \\
\hline Use of textbooks as basis for instruction & 0.748 & 0.434 & 0.690 & 0.462 & 0 & 1 \\
\hline Use of workbooks as supplement & 0.532 & 0.499 & 0.550 & 0.498 & 0 & 1 \\
\hline Use of workbooks as basis for instruction & 0.448 & 0.497 & 0.415 & 0.493 & 0 & 1 \\
\hline Frequency encourage students to improve performance & 2.797 & 0.498 & 2.779 & 0.521 & 0 & 3 \\
\hline Frequency monitor homework completed & 2.908 & 0.313 & 2.886 & 0.349 & 1 & 3 \\
\hline Emphasis on ongoing work for progress monitoring & 2.865 & 0.356 & 2.808 & 0.422 & 1 & 3 \\
\hline Emphasis on tests for progress monitoring & 2.660 & 0.500 & 2.528 & 0.605 & 1 & 3 \\
\hline Emphasis on central tests for progress monitoring & 2.098 & 0.725 & 1.941 & 0.772 & 1 & 3 \\
\hline Frequency relate lesson to students' daily lives & 2.204 & 0.813 & 2.467 & 0.745 & 0 & 3 \\
\hline Frequency send home progress report & 1.690 & 1.126 & 1.665 & 1.136 & 0 & 4 \\
\hline Frequency summarize what students should have learned & 2.588 & 0.688 & 2.609 & 0.674 & 0 & 3 \\
\hline
\end{tabular}

Sample of $4^{\text {th }}$-grade students in TIMSS 2011. Mean, standard deviation, minimum, and maximum of the basic, teacher, and teaching-method control variables included in the regressions. 
Table A7: The effect of classroom computer use by whether students use computers at home

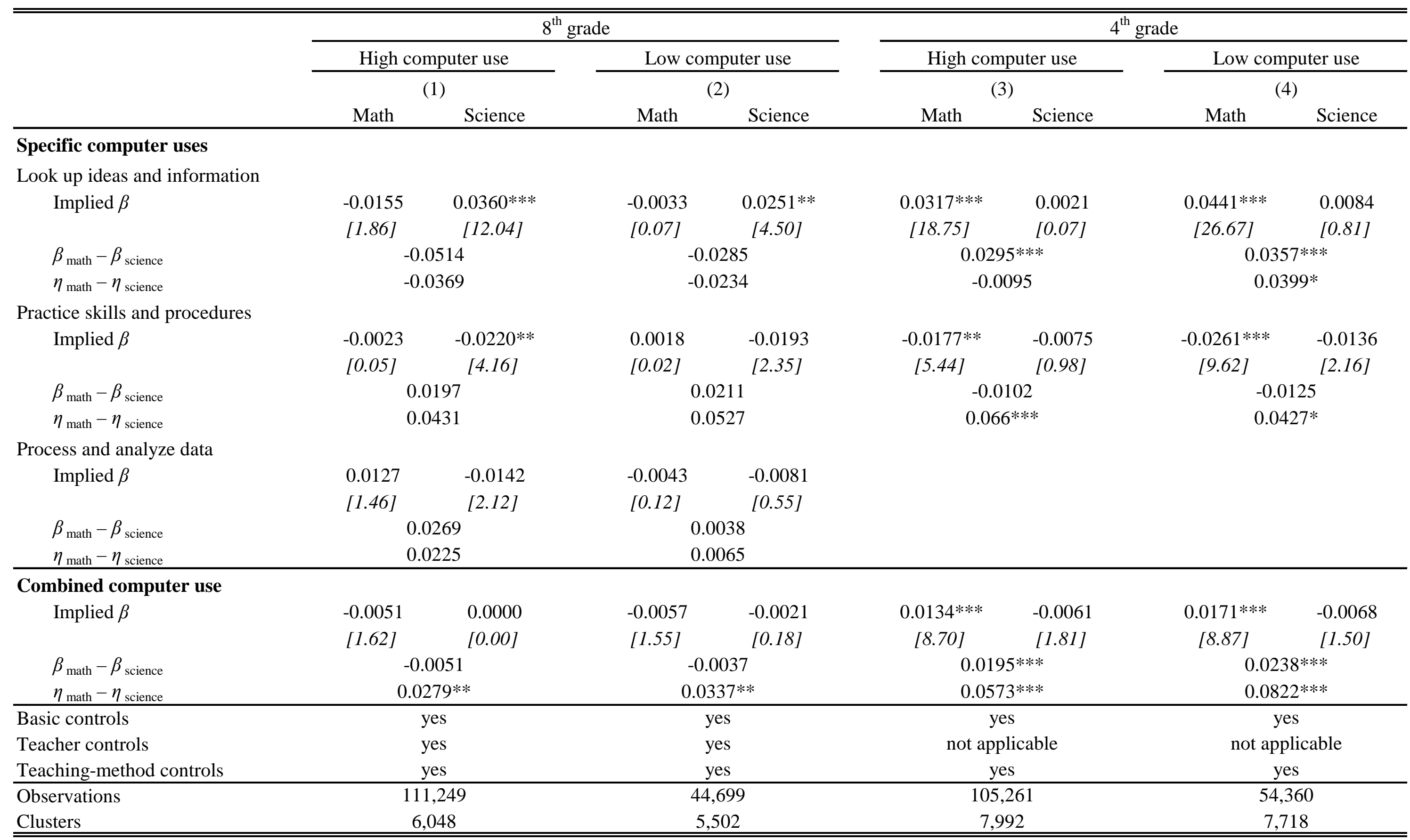

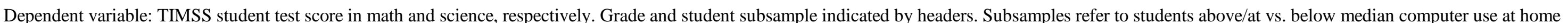

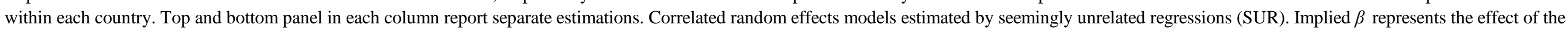
respective computer use category implied in the correlated random effects model, estimated according to equation (5). Regressions weighted by students' sampling probability. See Tables A3 and A5 in the appendix for lists of control variables. $\chi^{2}$ statistics adjusted for clustering at the classroom level in brackets. Significance levels: * $10 \%$, ** $5 \%$, *** $1 \%$. 
Table A8: The effect of computer use in high-income and low-income countries

\begin{tabular}{|c|c|c|c|c|c|c|c|c|}
\hline & \multicolumn{4}{|c|}{$8^{\text {th }}$ grade } & \multicolumn{4}{|c|}{$4^{\text {th }}$ grade } \\
\hline & \multicolumn{2}{|c|}{ High-income countries } & \multicolumn{2}{|c|}{ Low-income countries } & \multicolumn{2}{|c|}{ High-income countries } & \multicolumn{2}{|c|}{ Low-income countries } \\
\hline & \multicolumn{2}{|c|}{ (1) } & \multicolumn{2}{|c|}{$(2)$} & \multicolumn{2}{|c|}{ (3) } & \multicolumn{2}{|c|}{ (4) } \\
\hline & Math & Science & Math & Science & Math & Science & Math & Science \\
\hline \multicolumn{9}{|l|}{ Specific computer uses } \\
\hline \multicolumn{9}{|c|}{ Look up ideas and information } \\
\hline \multirow[t]{2}{*}{ Implied $\beta$} & 0.0083 & $0.0386 * * *$ & -0.0195 & 0.0072 & $0.0290 * * *$ & 0.0023 & $0.0477 * * *$ & 0.0053 \\
\hline & {$[0.54]$} & [15.65] & {$[1.81]$} & {$[0.27]$} & [11.80] & {$[0.07]$} & {$[22.76]$} & {$[0.20]$} \\
\hline$\beta_{\text {math }}-\beta_{\text {science }}$ & \multicolumn{2}{|c|}{$-0.0302 * *$} & \multicolumn{2}{|c|}{-0.0267} & \multicolumn{2}{|c|}{$0.0267 * *$} & \multicolumn{2}{|c|}{$0.0425 * * *$} \\
\hline$\eta_{\text {math }}-\eta_{\text {science }}$ & \multicolumn{2}{|c|}{$-0.0577^{*}$} & \multicolumn{2}{|c|}{0.0153} & \multicolumn{2}{|c|}{0.0248} & \multicolumn{2}{|c|}{0.0052} \\
\hline \multicolumn{9}{|c|}{ Practice skills and procedures } \\
\hline \multirow[t]{2}{*}{ Implied $\beta$} & $-0.0193 * *$ & $-0.0247 * *$ & 0.0029 & 0.0062 & $-0.0217 * * *$ & -0.0020 & $-0.0259 * *$ & -0.0063 \\
\hline & [4.27] & [5.97] & {$[0.03]$} & {$[0.17]$} & [6.88] & {$[0.05]$} & {$[5.47]$} & {$[0.31]$} \\
\hline$\beta_{\text {math }}-\beta_{\text {science }}$ & \multicolumn{2}{|c|}{0.0054} & \multicolumn{2}{|c|}{-0.0033} & \multicolumn{2}{|c|}{$-0.0197 *$} & \multicolumn{2}{|c|}{-0.0195} \\
\hline$\eta_{\text {math }}-\eta_{\text {science }}$ & \multicolumn{2}{|c|}{$0.0534 *$} & \multicolumn{2}{|c|}{0.0257} & \multicolumn{2}{|c|}{$0.0423^{* *}$} & & \\
\hline Process and analyze data & & & & & & & & \\
\hline Implied $\beta$ & 0.0103 & -0.0099 & 0.0076 & -0.0211 & & & & \\
\hline & {$[0.90]$} & [1.17] & {$[0.25]$} & {$[2.49]$} & & & & \\
\hline$\beta_{\text {math }}-\beta_{\text {science }}$ & & & & & & & & \\
\hline$\eta_{\text {math }}-\eta_{\text {science }}$ & & & & & & & & \\
\hline Combined computer use & & & & & & & & \\
\hline Implied $\beta$ & -0.0013 & 0.0044 & $-0.0097 *$ & -0.0078 & 0.0055 & -0.0004 & $0.0248 * * *$ & -0.0017 \\
\hline & {$[0.12]$} & [1.15] & {$[3.64]$} & {$[2.21]$} & [1.03] & {$[0.00]$} & {$[14.29]$} & [0.08] \\
\hline$\beta_{\text {math }}-\beta_{\text {science }}$ & & & & & & & 0.02 & \\
\hline$\eta_{\text {math }}-\eta_{\text {science }}$ & & & 0.0 & $* *$ & 0.06 & $* *$ & & \\
\hline Basic controls & & & & & & & & \\
\hline Teacher controls & & & & & not ap & able & not ap & able \\
\hline Teaching-method controls & & & & & & & & \\
\hline Observations & & & & & & & & \\
\hline Clusters & & & & & & & & \\
\hline
\end{tabular}

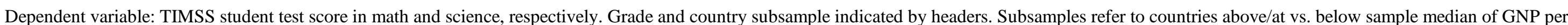

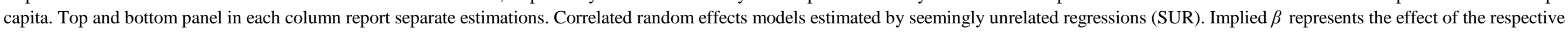

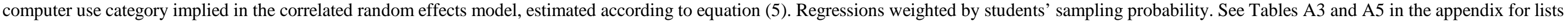
of control variables. $\chi^{2}$ statistics adjusted for clustering at the classroom level in brackets. Significance levels: * 10\%, ** 5\%, *** $1 \%$. 